September 2000 • NREL/TP-820-28944

\title{
The Role of Science and Technology in the Advancement of Women Worldwide
}

Irene D. Hays, Ed.D.

Barbara C. Farhar, Ph.D.

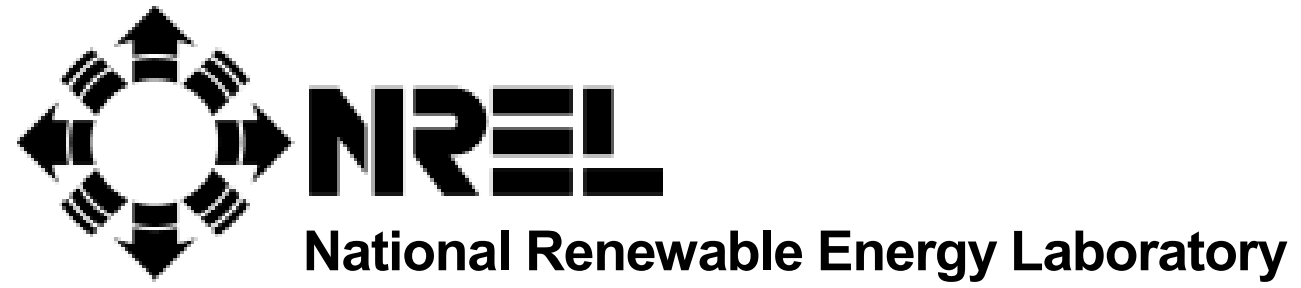

1617 Cole Boulevard

Golden, Colorado 80401-3393

NREL is a U.S. Department of Energy Laboratory

Operated by Midwest Research Institute $\bullet$ Battelle $\bullet$ Bechtel

Contract No. DE-AC36-99-G010337 


\section{The Role of Science and Technology in the Advancement of Women Worldwide}

Irene D. Hays, Ed.D.

Barbara C. Farhar, Ph.D.

Prepared under Task No. EROM.1000

This report can be viewed online at http://www.nrel.gov/docs/fy01osti/28944.pdf

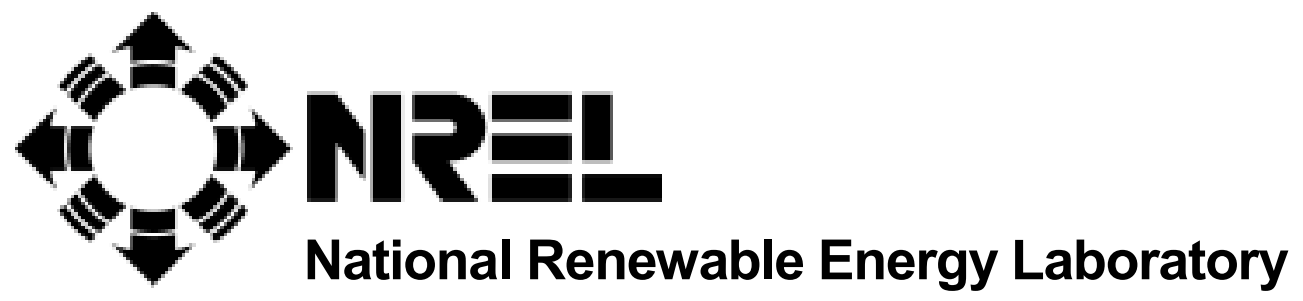

1617 Cole Boulevard

Golden, Colorado 80401-3393

NREL is a U.S. Department of Energy Laboratory

Operated by Midwest Research Institute • Battelle • Bechtel

Contract No. DE-AC36-99-G010337 


\section{NOTICE}

This report was prepared as an account of work sponsored by an agency of the United States government. Neither the United States government nor any agency thereof, nor any of their employees, makes any warranty, express or implied, or assumes any legal liability or responsibility for the accuracy, completeness, or usefulness of any information, apparatus, product, or process disclosed, or represents that its use would not infringe privately owned rights. Reference herein to any specific commercial product, process, or service by trade name, trademark, manufacturer, or otherwise does not necessarily constitute or imply its endorsement, recommendation, or favoring by the United States government or any agency thereof. The views and opinions of authors expressed herein do not necessarily state or reflect those of the United States government or any agency thereof.

Available electronically at http://www.doe.gov/bridge

Available for a processing fee to U.S. Department of Energy

and its contractors, in paper, from:

U.S. Department of Energy

Office of Scientific and Technical Information

P.O. Box 62

Oak Ridge, TN 37831-0062

phone: 865.576.8401

fax: 865.576.5728

email: reports@adonis.osti.gov

Available for sale to the public, in paper, from:

U.S. Department of Commerce

National Technical Information Service

5285 Port Royal Road

Springfield, VA 22161

phone: 800.553.6847

fax: 703.605.6900

email: orders@ntis.fedworld.gov

online ordering: http://www.ntis.gov/ordering.htm

Printed on paper containing at least $50 \%$ wastepaper, including $20 \%$ postconsumer waste 


\section{Preface}

This study was conducted in NREL's Science and Technology Education Programs Office and NREL's Center for Buildings and Thermal Systems. It was sponsored by the Office of Science, U.S. Department of Energy.

The authors would like to thank Antoinette Grayson Joseph, Director of Laboratory Policy and Infrastructure Management, U.S. Department of Energy, for her expert counsel and guidance on the design and conduct of the study.

Foremost among others who contributed to the completion of this study are the following experts who were interviewed: Suzanne Brainard, University of Washington; Patricia Campbell, Campbell-Kibler Associates; Joy Clancy, University of Twente, The Netherlands; Beatriz Clewell, The Urban Institute; Catherine Jay Didion, Association for Women in Science; Mildred Dresselhaus, Massachusetts Institute of Technology and U.S. Department of Energy; Yolanda S. George, American Association for the Advancement of Science; Sophia Huyer, Women in Global Science and Technology; Susan Kemnitzer, National Science Foundation; Martha Krebs, U.S. Department of Energy, and Interagency Steering Committee of the Commission on the Advancement of Women and Minorities in Science, Engineering, and Technology Development; Susan Staffin Metz, Women in Engineering Programs and Advocates Network; Kathleen Michels, National Institutes for Health; Beverley J. Morgan, Blooming Things, Limited, Jamaica; Wanda E. Ward, National Science Foundation; and Judi Wangalwa Wakhungu, Pennsylvania State University.

The following reviewers provided helpful comments and suggestions: Mildred Dresselhaus; Patricia Campbell; Joy Clancy; Sophia Huyer; Gail Karlsson, UN Development Programme; Judy Johnson, British Commonwealth Science Council; Shirley Malcom, American Association for the Advancement of Science; Cecily Celby, Radcliffe Institute for Advanced Study; and Linda Lung, National Renewable Energy Laboratory.

We are also grateful to NREL staff for their assistance: Paula Pitchford for editing the study report and Darlene Brenner and Pat Haefele for word processing. 


\section{Executive Summary}

As part of international work begun by the United Nations in 1946 to promote equal rights and opportunities for the world's women, participants at the Fourth World Conference on women (FWCW), held in Beijing, China in 1995, created a Platform for Action that focused on the following 12 critical areas of concern: women and poverty, education and training of women, women and health, violence against women, women and armed conflict, women and the economy, women in power and decision-making, institutional mechanisms for the advancement of women, human rights of women, women and the media, women and the environment, and the girl child. In each area, serious barriers to the well-being, equal treatment, and advancement of women still exist all over the world.

Nearly five years after this platform was published, the study described in this report was funded by the U.S. Department of Energy (DOE) and conducted by staff at DOE's National Renewable Energy Laboratory in Golden, Colorado. The study was undertaken initially to determine whether a compelling case could be made for considering science and technology as integral to the advancement of women in each of the areas of concern. The study took on a larger purpose when it became evident that a convincing-if not compelling - case had been documented in studies and publications prior to this one, but this evidence was not making an apparent difference in advancing women's status worldwide.

For this study, a literature review focused on relevant documents and declarations published in print and on the Internet before, during, and after the 1995 Beijing conference, concluding with resolutions published as outcomes of the UN Special Session held in New York in June 2000. Interviews were conducted with 15 women, most of whom are outstanding scientists and all of whom are experts on issues relating to women, science, and technology. Revealed were the experts' priorities on areas of concern, conclusions about the influences of science and technology on women's lives, views of women's unique actual and potential role in science and technology, and ideas for the future.

The experts agree that science and technology are decisively important tools for the advancement of women. They believe that women's involvement in the applications of science and technology will lead to beneficial and productive uses. They say that science and technology are particularly useful in four critical areas: education and training, economy (also linked with poverty), health, and communications/media. The experts also agree that the Internet is the one technology that most clearly appears to be embraced by both the developed and developing countries.

Analyses of the interviews revealed that, generally, there appear to be three perspectives on the role of science and technology in women's lives: pro-science, relativist, and skeptical. These differing perspectives may explain why communication is difficult among policy makers in governmental and international organizations and with scientists about the role of science and technology in the advancement of women.

The study resulted in recommendations related to women's contributions to science, including ethics of science; institutional barriers to advancing women; accountability in use of resources for women's advancement; changes in science education, and the need for dialogue among those with differing perspectives on the role of science and technology in the advancement of women. 


\section{Contents}

$\underline{\text { Page }}$

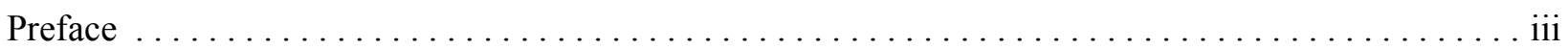

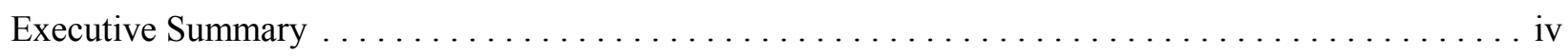

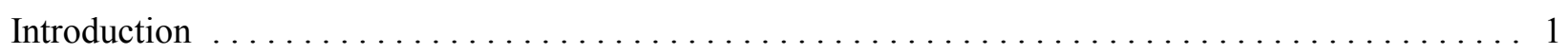

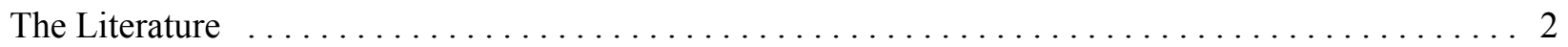

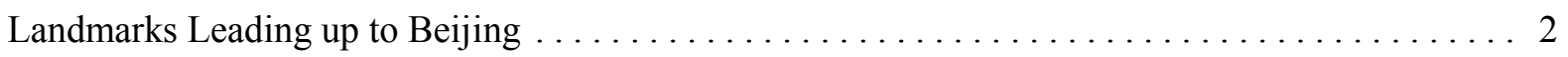

Preparing the Beijing Platform for Action $\ldots \ldots \ldots \ldots \ldots \ldots \ldots \ldots \ldots \ldots \ldots \ldots$

The Once and Future Action Network $\ldots \ldots \ldots \ldots \ldots \ldots \ldots \ldots \ldots \ldots \ldots \ldots$

Fourth World Conference on Women: Platform for Action (PFA) and Follow-Up . . . . . . . 6

World Conference on Science, Budapest, Hungary $\ldots \ldots \ldots \ldots \ldots \ldots \ldots \ldots \ldots \ldots \ldots$

Asia Pacific Economic Cooperation and U.S. National Science and Technology Council . . . . . 9

WomenWatch: Online Working Groups $\ldots \ldots \ldots \ldots \ldots \ldots \ldots \ldots \ldots \ldots \ldots \ldots \ldots$

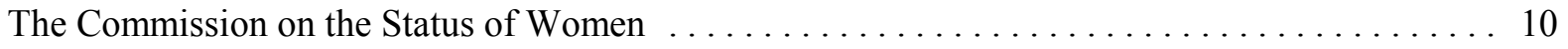

Beijing +5 Women 2000: Gender Equality, Development and Peace for

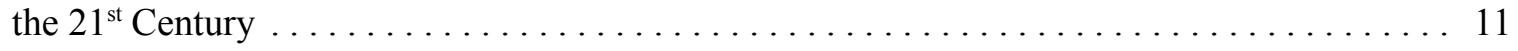

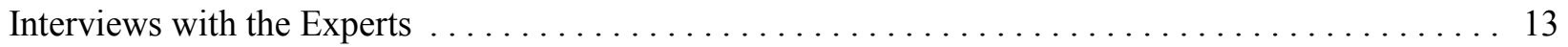

Why Science and Technology Have Not Yet Been Incorporated: The Views of the Experts $\ldots \ldots 13$

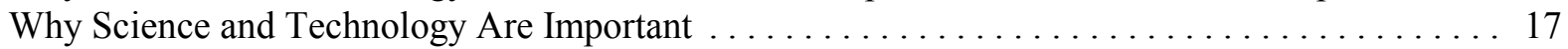

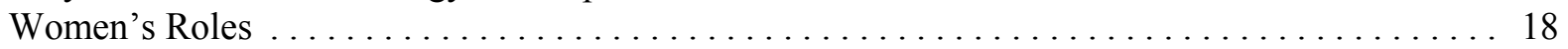

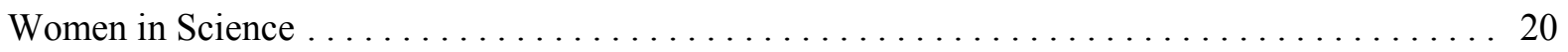

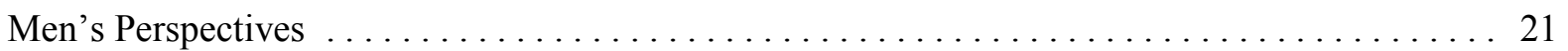

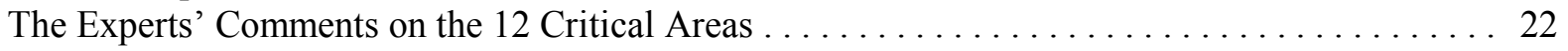

The Top Four Critical Areas Identified by the Experts Interviewed $\ldots \ldots \ldots \ldots \ldots \ldots \ldots \ldots 22$

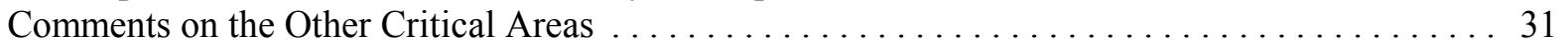

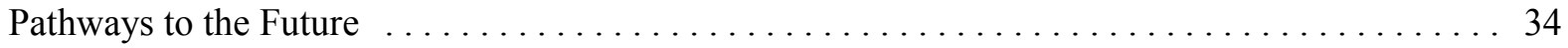

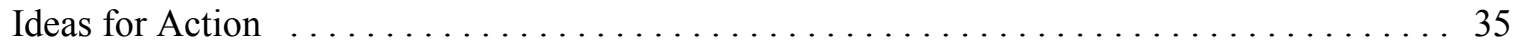

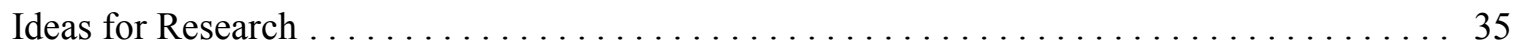

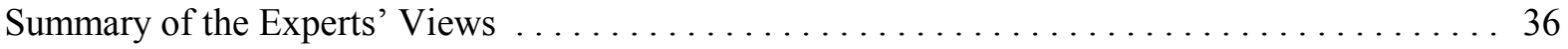

Analysis, Conclusions, and Recommendations $\ldots \ldots \ldots \ldots \ldots \ldots \ldots \ldots \ldots \ldots \ldots \ldots$

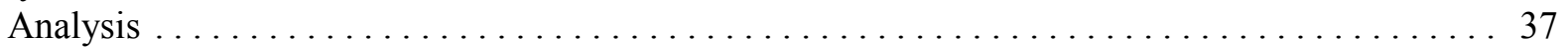

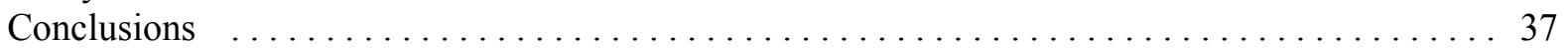

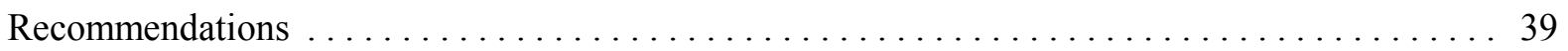

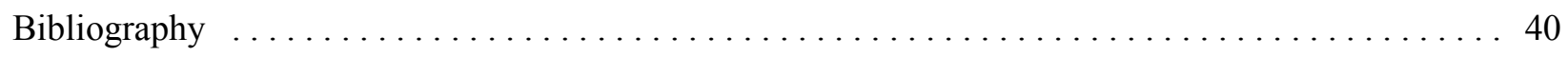

Appendix A. The 12 Critical Areas for the Advancement of Women Defined in 1995 by the U.N. Conference on Women in Beijing, China ..... 43

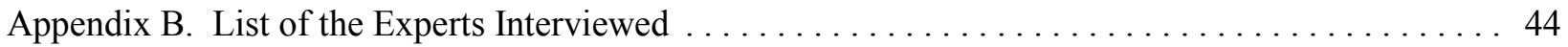




\section{Contents (concluded)}

Appendix C. Examples of Uses of Science and Technology for the Advancement of Women That the Experts Recommend Should be Further Investigated . . . . . . . . . . . 45

Appendix D. Additional Examples of the Role of Science and Technology in Advancing Women . . . 47

Communications ................................. 47

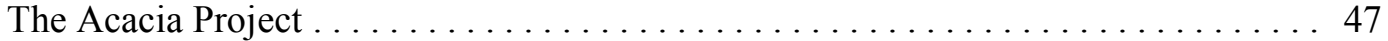

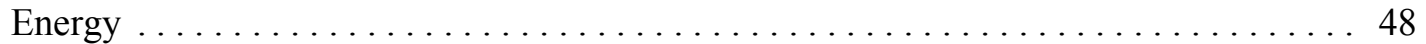

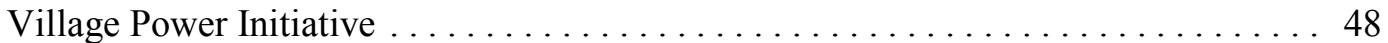

Vietnam Women's Union Project . . . . . . . . . . . . . . . . . . . . . . . 49

Gender and Energy Implications for Health in Tibet $\ldots \ldots \ldots \ldots \ldots \ldots \ldots \ldots$

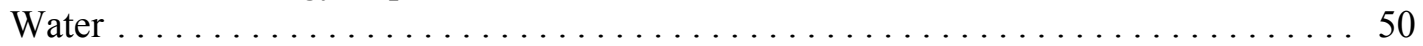

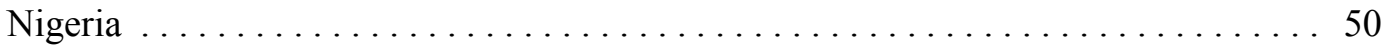

Appendix E. Prince Charles Attacks the Scientific Community $\ldots \ldots \ldots \ldots \ldots \ldots \ldots \ldots \ldots$

\section{List of Tables}

Table 1. Chronology of Key Events Relevant to Science and Technology and the Platform for Action of the Fourth World Conference on Women, Beijing, China, 1995 


\section{Introduction}

Building on the insight, voices, and work of countless women and the many organizations that support them, this study was undertaken to determine whether a convincing - perhaps even compelling - case could be made for considering science and technology as important and integral to the advancement of women worldwide. At the Fourth World Conference on Women (FWCW) held in 1995 in Beijing, China, the participants defined 12 critical areas of concern for women: women and poverty, education and training of women, women and health, violence against women, women and armed conflict, women and the economy, women in power and decision-making, institutional mechanisms for the advancement of women, human rights of women, women and the media, women and the environment, and the girl child. This study took on a larger purpose when it became evident that a strong case had already been made for the integral and critical role of science and technology in the advancement of women. A convincing - if not compelling - case was documented in studies and publications prior to this one, but this evidence was not making an apparent difference in advancing women's status worldwide.

The study included two main approaches to gathering information: (1) a review of the published literature and Internet postings related to key events that both preceded and followed the FWCW, and (2) interviews of selected key experts, most of whom are women scientists and all of whom have long been concerned with issues relating to women, science, and technology.

The first section of this report, the literature review, discusses key events in the history of women in relation to science and technology and shows that these concerns date back more than half a century. The following sections synthesize findings from the open-ended interviews and reveal surprising insights that help answer the questions of this study. Finally, the report draws conclusions and makes recommendations that reveal a vision for women worldwide and suggest future plans of action to help realize that vision. ${ }^{1}$

${ }^{1}$ One of the purposes of the FWCW was to "look at the world through women's eyes." That this gendered perspective is significant has been pointed out by Shirley Malcom, among others: "It matters not only in terms of who is doing the observing but also the vantage point they have" (Malcom 1999). Those conducting this study have the vantage point of professional, white, middle-class women in the United States. Despite every effort to step into the perspectives of others, the observers' roots inevitably affect the study approach and outcomes, regardless of who prepares a study. Often, truth and insights emerge in the juxtaposition of diverse views of reality. 


\section{The Literature}

A plethora of literature related to the topic of this study has been generated before, during, and after the conference in Beijing in 1995 and in preparation for the Beijing +5 meeting in New York in 2000. The authors reviewed a wide variety of these discussions and documents, including articles and reports provided or written by the experts interviewed. Not all are summarized here, but major documents related to the key events noted in Table 1 are summarized in this section of the report.

Table 1. Chronology of Key Events Relevant to Science and Technology and the Platform for Action of the Fourth World Conference on Women, Beijing, China, 1995

\begin{tabular}{|l|l|}
\hline Date & Event \\
\hline 1946 & UN Commission on the Status of Women (CSW) established \\
\hline 1975 & First UN World Conference on Women, Mexico City, Mexico \\
\hline $1976-1985$ & UN Decade for Women: Equality, Development, and Peace \\
\hline 1979 & $\begin{array}{l}\text { UN Conference on Science and Technology for Development adopts Vienna } \\
\text { Programme of Action including Resolution on Science and Technology for Women, } \\
\text { Vienna, Austria }\end{array}$ \\
\hline 1979 & $\begin{array}{l}\text { The Convention on the Elimination of Discrimination Against Women (CEDAW) } \\
\text { adopted by the UN General Assembly }\end{array}$ \\
\hline 1980 & Second UN World Conference on Women, Copenhagen, Denmark \\
\hline 1983 & $\begin{array}{l}\text { UN Advisory Committee on Science and Technology for Development } \text { Ad Hoc Panel } \\
\text { on Science, Technology, and Women issues recommendations }\end{array}$ \\
\hline $1993-1995$ & $\begin{array}{l}\text { Third UN World Conference on Women, Nairobi, Kenya publishes Forward-looking } \\
\text { Strategies for the Advancement of Women }\end{array}$ \\
\hline $\begin{array}{l}\text { UN Gender Working Group completes study and report; Science and Technology for } \\
\text { Sustainable Human Development: The Gender Dimension and Missing Links, } \\
\text { publication based on study report }\end{array}$ \\
\hline 1994 & Once and Future Action Network (OFAN) established \\
\hline $\mathbf{1 9 9 5}$ & $\begin{array}{l}\text { Fourth UN World Conference on Women (FWCW), Beijing, China, issues Platform } \\
\text { for Action (PFA) }\end{array}$ \\
\hline 1995 & UN Gender Advisory Board established \\
\hline 1999 & $\begin{array}{l}\text { UNIFEM study in preparation for the World Conference on Science: Women Making } \\
\text { a Difference in Science and Technology }\end{array}$ \\
\hline 1999 & UNESCO World Conference on Science, Budapest, Hungary \\
\hline 1999 & $\begin{array}{l}\text { WomenWatch Online Working Groups and UN Commission on the Status of Women } \\
\text { prepare for UN Special Session to appraise progress on implementing the Nairobi } \\
\text { Forward-Looking Strategies and Beijing Platform for Action }\end{array}$ \\
\hline $\begin{array}{l}\text { Beijing +5: Women 2000: Gender Equality, Development and Peace for the 21 } 1^{\text {st }} \text { Century, } \\
\text { UN Special Session conducted, New York }\end{array}$ \\
\hline
\end{tabular}

\section{Landmarks Leading up to Beijing}

The UN Commission on the Status of Women (CSW), established in 1946, is charged to promote the implementation of the principle that men and woman shall have equal rights in political, economic, civil, social, and educational fields. Since 1946, the Commission's mandate and membership have expanded, 
including support for a series of UN conferences that have included gender equity either as a component or major focus, beginning with the First World Conference on Women held in Mexico City in 1975. That conference launched the "Decade for Women" (1976-1985), during which the status and rights of women were examined worldwide.

More than 30 years of work by the CSW culminated in the adoption by the UN General Assembly in 1979 of the Convention on the Elimination of All Forms of Discrimination against Women (CEDAW). The Convention - often described as an international bill of rights for women-defines what constitutes discrimination against women and the actions needed to end that discrimination. Although women's participation in science and technology was not a major focus of the Convention, the language encompassed the science and technology agenda by calling for changes to (1) eliminate "prejudices and customary and all other practices which are based on the idea of the inferiority or the superiority of either of the sexes or on stereotyped roles for men and women" and (2) ensure equal rights between the sexes with regard to education and employment (United Nations 1979).

The Convention reflects several specific recommendations for women made in a resolution on Science and Technology for Women included in the Vienna Programme of Action, the outcome of the UN Conference on Science and Technology for Development held earlier that same year (1979) in Vienna, Austria. The Programme resolved to ensure the full participation of women in science and technology, including participation in the development and selection of technologies. Later, in 1983, a panel of specialists on science and technology for women was organized by the Advisory Committee on Science and Technology for Development. This panel, organized in cooperation with the American Association for the Advancement of Science, issued a study report that combined two important issues: science and technology for development and equal participation of women. This panel report later became an important input for the World Conference to Review and Appraise the Achievements of the UN Decade for Women, held in Nairobi, Kenya, in 1985.

At the Second World Conference on Women held in Copenhagen, Denmark, in 1980, the international consensus on measures to be taken for the advancement of women was further elaborated. The Conference adopted a program of action for the second half of the decade (1976-1985) for women.

The Third World Conference on Women in 1985 in Nairobi, Kenya, set forth the Forward-looking Strategies for the Advancement of Women, to be implemented by the year 2000. Among the issues addressed in Nairobi were those later identified as critical areas of concern in the Platform for Action (PFA) of the FWCW. Although science and technology were not called out as a separate area of focus, the Nairobi conference called for the

full and effective participation of women in the decision-making and implementation process related to science and technology including planning and setting priorities for research and development and the choice, acquisition, adaptation, innovation and application of science and technology for development (United Nations 1986).

Included also was the recommendation that women be provided increased opportunities and encouraged to study science, mathematics, and engineering at all levels of the education continuum, as well as equal access to science and technology jobs and equal opportunities for advancement within the scientific professions. Acknowledged were women's roles as intermediaries between the natural environment and society-with respect to agro-ecosystems, safe water and food (i.e., sanitation), and as producers, users, and managers of 
energy resources - and that women are and should be involved at all levels of decision-making and implementation.

The CSW was charged with tracking the implementation of the Nairobi strategies. In light of the remaining work needed for full implementation, the CSW decided that the agenda for the FWCW should include reviewing and appraising the implementation of the Nairobi agenda.

Issues related to the advancement of women were also addressed in a series of UN international conferences not entirely or specifically focused on women's issues, such as the UN Conference on Environment and Development, Rio de Janeiro, 1992; UN Conference on Human Rights, Vienna, 1993; International Conference on Population and Development, Cairo, 1994; World Summit for Social Development, Copenhagen, 1995; and UN Conference on Human Settlements (Habitat II), Istanbul, 1996. Each conference agenda and subsequent program and call for action affirmed the need and commitment to advance the status of women worldwide. In Rio de Janeiro and in Cairo, specific reference was made to the role of science and technology in the advancement of women in areas of the environment and health.

\section{Preparing the Beijing Platform for Action}

In preparation for the FWCW, the newly established United Nations Commission on Science and Technology for Development (UNCSTD) set up a Gender Working Group (GWG) in 1993 to address the topic of gender as it relates to science and technology. The GWG identified specific ways in which women may be empowered by gaining access to scientific and technological knowledge. The outcome of the GWG is especially relevant to this study.

The GWG was made up of eight UNCSTD members (all men), eight women expert advisors, and others who assisted. Three-fourths of the GWG were from developing countries. The GWG commissioned essays to distinguished scholars and experts to explore issues related to science and technology and provide examples in which technical change had affected the lives of women and men. The essays focus primarily, but not exclusively, on the basic needs of people in rural areas of the developing world (UNCSTD 1995).

Among other things, the report includes recommendations to governments to adopt goals of parity in education and in career opportunities for women and men in science and technology; gender equity in science and technology institutions, including setting research priorities, and in technology design, transfer, and application; equal access for women and men to scientific and technological knowledge related to quality of life; and recognition of local knowledge systems as being complementary to modern science and technology and valuable for sustainable human development.

Central to the GWG study are the expert papers and analyses commissioned by the GWG. The papers include examples of the role of science and technology in the lives of women worldwide, illustrating women's contributions and involvement in a number of the critical areas of concern that were identified later in the Beijing PFA. Among the concerns discussed are indigenous agricultural practices (such as breeding sweet potato plants); traditional midwifery (technology and training related to health care); and sustainable water supplies (theory of access and transport, pump assembly, installation, monitoring and repair). Results of the GWG are included in CSTD (1995) which contains the papers in full commissioned by the GWG.

The study papers led the GWG to identify the following seven key areas for transformative action: (1) gender equity in science and technology education; (2) removing obstacles to women in scientific and technological 
careers; (3) making science responsive to the needs of society - the gender dimension; (4) making the science and technology decision-making process more gender aware; (5) relating better with local knowledge systems; (6) addressing ethical issues related to gender in science and technology; and (7) improving the collection of gender disaggregated data for policy makers. Concrete recommendations for actions in each key area were intended to support women's participation in leadership and decision-making and improve women's status worldwide.

The GWG report recommended to the United Nations certain policies, guidelines, and procedures - both formal and informal - related to gender and recommended that it establish an Advisory Board on Gender. The UN established that Board in 1995 to provide advice to UNCSTD and oversight of activities that support national governments and UN agencies in implementing the GWG recommendations.

Ideas, information, and examples found in the GWG report provide compelling information illustrating how important science and technology are to women's advancement in the 12 critical areas of concern identified in the Beijing PFA. If such rich data alone were enough to make clear the importance of science and technology in the lives of women worldwide, the case would have been made by the GWG report. Why the case has not been convincingly made remains a question for this and future studies.

The main findings of the GWG study were communicated to the preparatory committee meetings for the FWCW, including the five international regional preparatory conferences: (1) Asia and Pacific, Jakarta, January 1995; (2) Africa, Dakar, December 1994; (3) Latin America, Mar del Plata, January 1995; (4) Europe, Vienna, January 1995; and (5) Arab nations, Amman, February 1995. Subsequently, all five regional Platforms for Action (PFAs) recognized that science and technology are integral to other issues that affect women, though emphases and priorities differ from region to region.

\section{The Once and Future Action Network}

The Once and Future Action Network (OFAN), established in 1994 to advocate for women, is an international grassroots network comprising individual women and more than 100 intergovernmental and nongovernmental organizations (NGOs), research institutes, universities, and other groups. OFAN influenced the language and amendments of the international regional PFAs in preparation for the FWCW. OFAN's advocacy activities brought to the forefront a gender perspective related to the advancement of the world's women through science and technology. Themes and issues identified and shared by OFAN locally, regionally, and internationally supported the role of women as active participants in the application of science and technology as well as in formulating policies that reflect women's perceptions and concerns.

In Beijing, OFAN played an important role at a forum conducted for NGO by hosting the Once and Future Pavilion at the FWCW. There, OFAN brought forth its vision of a world in which women are full partners in science and technology decision-making and application. Displays, presentations, and workshops exhibited women's traditional, rich knowledge and highlighted the contributions of women in science and technology. Major contributions from supportive organizations enhanced the effectiveness of the Pavilion, such as a mentoring workshop offered by the Association for Women in Science and support from the U.S. Department of Energy. If passion, vision, real-life demonstrations, and vivid illustrations of women's role in science and technology were by themselves compelling enough to establish the link between women's advancement and science and technology, the OFAN effort would have done so.

As a consequence of OFAN's preparation and that of many other organizations, science and technology were included in seven of the 12 critical areas of concern in the Draft PFA and were mentioned most often in the 
areas of access to education and training and participation in the definition of economic structures. Science and technology were also identified as playing a crucial role in the areas of poverty, health, communications systems and media, women and the environment, and the girl child. Set aside for negotiations at the FWCW was language relating science and technology to women's reproductive and sexual health; military expenditures and violence against women; land mine planting and export; and ownership and control of land, other properties, and natural and capital resources.

\section{Fourth World Conference on Women: Platform for Action (PFA) and Follow-Up}

Although a number of countries at the $1995 \mathrm{FWCW}$ expressed reservations about selected language or intent in the PFA, all countries supported by consensus the adoption of the 38-paragraph Declaration and 395paragraph PFA. Even though science and technology are not specifically identified as one of the 12 critical areas of concern, at least 40 separate recommendations in the PFA recognize science and technology as means of advancing the world's women. Science and technology are particularly strong in the areas of women and the economy, the education and training of women, and women and the environment. In these areas, science and technology are described as tools to women's advancement. Nevertheless, only in the section dealing with women and the environment are women seen as having a role in the ethics and direction of scientific research.

The PFA not only describes how science and technology can assist women's advancement, it also acknowledges the negative impacts that science and technology may have on the lives of women, and men as well. Specifically, negative impacts can be found in expenditures for the military and nuclear research, portrayal in the media of stereotyped and demeaning images of women, and the degradation and pollution of the environment.

The PFA makes no specific mention of science and technology in the areas of violence against women, women and armed conflict, and human rights for women. However, the platform notes that women and children suffer greatly in situations of armed conflict and that women's involvement in science and technology can diminish the impact of traditional stereotyped roles that may lead to abuse of women. Involvement in science and technology is also seen as helping women become less dependent on men and less vulnerable in terms of economic security or physical safety. Overall, science and technology are addressed in the following critical areas of concern: women and poverty; education and training of women; women and health; women and the economy; women in power and decision-making; women and the media; women and the environment; and the girl-child.

UN General Assembly action following the FWCW included the endorsement of a call to governments, the UN system, and other key groups to implement the PFA by promoting active, visible policies of mainstreaming a gender perspective at all levels. The General Assembly called on governments to develop comprehensive implementation strategies and plans of action and asked governments and NGOs to disseminate widely the Beijing Declaration and PFA and to include NGO contributions in the design and implementation of strategies and national plans.

The General Assembly also directed the CSW to engage in a follow-up process, regularly reviewing and monitoring the PFA's critical areas of concern. Thus, the CSW would continue its decades-long role of being a catalyst for improving the status of women worldwide.

In early 1996, an opportunity for reflection and follow-up to the FWCW took place at the $8^{\text {th }}$ International Conference of the Gender and Science and Technology Association (GASAT) in Ahmedabad, India. Held 
in a developing country for the first time, this GASAT conference was also the first at which more of the 300 participants were from the South than from the North. The conference focused on sustainable development and women's roles in education, employment, equality, and empowerment. Numerous gender and science and technology issues, covering many topics and all areas of the world, were presented and discussed. Many of the issues related directly to the critical areas of concern in the PFA.

Critical to the success of follow-up and implementation is the issue of equitable access to communications and information about the outcome of the FWCW. This issue was addressed in the PFA and in the NGO communications strategy for disseminating and implementing the resolutions of the FWCW. On this important topic, in early 1997, the Women in Global Science and Technology (WIGSAT) completed a study concerning African women's access to and use of information and communications technologies. WIGSAT is an international network concerned about critical issues in science and technology for development. The 1997 study revealed the gendered nature of the systems within which women seek to meet their information and communications needs. The study made a strong connection between women's advancement in critical areas of concern and women's skills, knowledge, and access to information technology. The study results do not apply only to African women, they also reflect the needs of developing countries worldwide.

\section{World Conference on Science, Budapest, Hungary}

In preparation for the World Conference on Science (WCS), organized by the United Nations Educational, Scientific, and Cultural Organization (UNESCO) and the International Council for Science, a literature search and survey questionnaire were completed by the United Nations Development Fund for Women (UNIFEM). The results led to numerous case studies as examples of women making a difference in science and technology. These case studies illustrate the value of increasing women's access to science and technology as well as their control over the design and direction of scientific and technological pursuits, including recognition of women's indigenous knowledge and technologies (UNIFEM 1999) .

The case studies comprise a sampling — certainly not exhaustive — of women's activities, contributions, inventions, and innovations in science and technology. They document how women approach activities in science and technology and determine priorities; provide unique perspectives; apply existing technologies in innovative, people-centered ways; transform science and technology; implement international commitments on gender, science, and technology; and add value to science and technology in ways that benefit women, the community, the economy, and the larger society.

Among several dozen examples cited in this study are historical ones, such as Barbara McClintock's Nobelprize-winning discovery and her way of viewing the study of genetics, and Jane Goodall and Diane Fossey's approach to studying primate behavior, which resulted in a new model for wildlife observation. These women brought feelings and relationships into their work - a departure from the traditional masculine approach to science. Contemporary examples include women inventors from around the world; women in formal and applied science and technology - and a blending of the two; and women in science and technology entrepreneurship, education, and advocacy organizations. Topics represented included women in field and laboratory science and technology; information and communications technology; astronomy, manufacturing, energy production and use, biodiversity, water management, livestock, agro-forestry, agriculture, and food technology; and model education and entrepreneur efforts in Africa, Brazil, China, Uganda, and the Philippines. Also included are case studies of a number of women's organizations such as OFAN, the Third World Organization for Women in Science (TWOWS), Ecowomen, and the Forum for African Women Educationalists. Some less formal, but no less effective, organizations were also cited, such 
as a consortium of women in Peru who developed a way to generate more income through textile production in their homes.

This UNIFEM study provides yet another opportunity to wonder what more is required to build a compelling case for the role of science and technology in the advancement of women worldwide and, conversely, a case for the role of women in advancing science and technology.

At the Budapest 1999 WCS, Gender Mainstreaming in Science and Technology was discussed at a thematic meeting. Following their deliberations, the members delivered a set of proposals suggesting changes to the draft Declaration and draft Science Agenda; most of the changes were incorporated. The chief conclusions of the presentations at the thematic meeting were as follows (UNESCO and ICSU 1999):

- Inequality exists between boys and girls, women and men, in access to the use or to the benefit of science and technology, and in the opportunity to act as agents in the development and control of science, engineering, and technology for human survival and improvement of the quality of human life (Sjamsiah Achmad, Indonesian Institute of Science, Indonesia).

- Policies and plans for the use of science and technology for sustainable development are gender insensitive and do not respond to the needs and aspirations of both men and women equitably. Gender planning is not an end in itself but a means to bring a different perspective and a new intellectual dimension to the development process - one that does not generate merely growth but rather, growth with justice and equity (Senator Dr. Farkhonda Hassan, Vice-President, TWOWS, Egypt).

- Research by women scientists in African countries, though very small in amount, is an extension of the home, and concerned with agriculture, health, nutrition, and education; i.e., these are peaceful activities as against research in physics, biology, chemistry, and technology, which is more concerned with activities leading to war and domination. What greater role could these women play? They could promote science as a learning process, a way of doing things that links scientific knowledge directly to tools for overcoming barriers for women (Grace Alel Williams, Vice-President, TWOWS, Nigeria).

- A gender-fair scientific education is key to achieving the goal of scientific education for all (Gloria Bonder, Universidad de Buenos Aires, Argentina).

- An essential role of women scientists is to change the "global intolerables" into developmental opportunities - for turning population explosion into reproductive health, poverty and environmental degradation into sustainable human development, and violence into peace and cooperation. All the knowledge and creativity of both men and women in science are needed for this change (Aleksandra Kornhauser, International Centre for Chemical Studies, University of Ljubljana, Slovenia).

- Girls and women, as half of the world's population, must be viewed as intellectual assets and provided opportunities to enhance their education. Women often play special roles within the society and the family that makes it even more important that countries invest in their education and literacy in science and technology (Shirley Malcom, American Association for the Advancement of Science, USA).

The 1999 WCS concluded that women must be full-share partners and participants in all aspects of science and technology. Two principal documents were produced and adopted by the WSC (UNESCO and ICSU 1999a,b). The documents stress the vital importance of removing obstacles to women's participation at every level and in every arena in which women are marginalized. These arenas include education, professional 
participation, the media, gender data collection and presentation, assessment and evaluation of the progress of women, representation of women in policy and decision-making, networking, and documentation of the contributions of women in science and technology. The documents call for support and action on behalf of the WCS Declaration on Science and Framework for Action by governments, educational institutions, scientific communities, NGOs, and civil society, with support from bilateral and international agencies.

\section{Asia Pacific Economic Cooperation and U.S. National Science and Technology Council}

Referencing the Beijing Declaration and PFA as extraordinary statements on the need to empower women, the Asia Pacific Economic Cooperation (APEC) conducted a Ministerial Meeting on Women in 1998, the result of which was a mandate to develop a framework for integrating women into APEC. The idea for the meeting and framework grew from the recognition that women and children were bearing the brunt of the financial crisis that began in Asia and spread to the rest of the world and, consequently, the role and status of women were economic imperatives.

With gender as a crosscutting issue, the APEC developed a framework based on three elements identified as essential to reinforcing the importance of women's roles in economic development. These elements are (1) gender analysis; (2) the collection and use of sex-disaggregated data, particularly in science and technology; and (3) increased participation of women in APEC. The framework could have a far-reaching positive impact, affecting the social and economic well-being of the Asian-Pacific region. It could help identify and eliminate barriers to women's full participation in the economy; create a leading-edge workforce; increase the ability of women to respond to economic opportunities; integrate the economic interests of women into economic recovery and future prosperity; and broaden support for APEC through greater participation and decision-making among women.

Around the world, women are underrepresented in science and technology activities and careers that support economic stability and growth, especially in developing countries. However, even in more developed countries, such as the United States, women, along with certain ethnic minority groups, are also underrepresented to the extent that any nation's economic viability may be threatened.

In the United States, the National Science and Technology Council (NSTC) recently issued a report (NSTC 2000) on the U.S. scientific, technical, and engineering workforce. A fundamental conclusion is that the national interest requires the vigorous development of a science, technology, and engineering workforce that includes all ethnic and gender groups. To continue its leadership in science and technology, the United States must have a diverse workforce and draw upon the full talent pool of the nation. Demographic trends point to a heightened need to increase the percentage of women in the science and technology workforce to ensure the future availability of skilled, competent workers.

\section{WomenWatch: Online Working Groups}

In late 1999, in preparation for the Beijing +5 UN Special Session, WomenWatch conducted online working groups on the 12 critical areas of concern in the Beijing PFA (WomenWatch 2000). WomenWatch is a UNinitiated interagency information network on women's concerns, progress, and equality. Many UN organizations participate. The results of the working groups provide important guidelines for future work toward implementing the PFA. The approximately 10,000 members of the working groups represented more than 120 countries and included NGOs, government representatives, intergovernmental organizations, and 
researchers. The working groups focused on identifying (a) policies, legislation, strategies, and partnerships that have been successful in furthering women's equality; (b) case studies, best practices, and examples of successful government business and civil society efforts as well as lessons learned; and (c) remaining obstacles to progress and how they can be overcome.

The results represent the broad experiences of those working for gender equality and provide an excellent resource of ideas and strategies that can be adapted and adopted locally or nationally. Lessons learned, illustrated by example or quotation, and shared "good practices," taken together, reveal some crosscutting obstacles and common trends. Highlights of the discussions include the importance of early childhood education, women-created health-care services, new legislation and policies on women's rights and representation, new ways of addressing conflict, crossing ethnic divisions to build peace, and creating and fostering new partnerships for women's equality.

Discussions by the working groups were summarized in a report submitted to the CSW which acted as the Preparatory Committee for the UN Special Session: Beijing + 5, June 2000. Before the Special Session, the UN General Assembly charged the CSW to identify emerging issues, trends, and new approaches to issues affecting the situation of women, or equality between women and men, and to make substantive recommendations.

\section{The Commission on the Status of Women}

At its $43^{\text {rd }}$ session in March 1999, the CSW posed the agenda and documentation for the UN Special Session. The committee also proposed a framework for identifying further actions and initiatives and five functional categories for their elaboration. The CSW also presented four broad themes that cut across the 12 critical areas of concern and that have emerged as issues or become more pertinent since 1995. One of the crosscutting themes focused on women, science, and technology and the new information age.

The Beijing PFA calls attention to the potential of science and technology to contribute positively to women's advancement in several of the critical areas of concern that could be impacted by communications, the media, and information technologies. In assessing the progress made since 1995, the CSW noted that, to implement these recommendations, further actions and initiatives are needed by the telecommunications industry, the international community, and governments.

The CSW also noted that huge gaps in knowledge of science and technology, and access to them, exist between the rich and the poor-among which women are disproportionately represented - and between women in traditional communities and those in modern communities. The disparities in access to training in science and technology result in an underrepresentation of women in careers in these fields. The need is great for women to influence the development of science and technology and be actively involved in defining and developing new information technologies. Women's participation in decision-making regarding communications technologies could have a positive effect on the negative stereotyping and discrimination against women often found in the media. Sexual harassment could also be reduced if more women were trained to recognize such stereotyping and discrimination.

Concerns that priority should be given to women's basic sustainable needs, such as food and shelter, rather than tools like the Internet and other technologies, have been countered by arguments that meeting basic needs and accessing electronic networks and other technologies are not mutually exclusive. Changes in access to communications technologies have led to new entrepreneurial activities among women in some 
developing countries. Communications technology can reduce isolation for women and open access to knowledge not otherwise available.

Further discussions at the $44^{\text {th }}$ session of the CSW in March 2000 recognized a need to integrate women's knowledge and priorities in the conservation and management of environmental resources to ensure their sustainability. Women's customary knowledge, management, and sustainable use of biodiversity were recognized as playing a crucial role in preserving and protecting environments. The need to ensure women equal access to education in science and technology was also set forth.

\section{Beijing +5 Women 2000: Gender Equality, Development and Peace for the $21^{\text {st }}$ Century}

Five years after the 1995 FWCW in Beijing, the UN General Assembly met in New York to review and appraise the implementation of the Beijing Platform for Action. This special session, "Women 2000: Gender Equality, Development and Peace for the Twenty-first Century," adopted by consensus a Political Declaration and an outcomes document on future actions and initiatives. These two resolutions not only strongly reaffirm that governments are responsible for implementing the Beijing PFA, they also strengthen several of the 12 critical areas of concern and include additional new issues that emerged or gained importance in the five years since the FWCW.

A critical concern specifically addressed in the outcomes document is the area of women and health. Of particular concern are the gender aspects of the human immunodeficiency virus/acquired immune deficiency syndrome (HIV/AIDS) pandemic and sexually transmitted infections (STIs); malaria and tuberculosis and their disproportionate impact on the health of women and girls; attention to the mental health of women and girls; and specific provisions on healthy, active aging. Progress is evident in the area of human rights and the issue of violence against women, with specific attention to removing all provisions that discriminate against women by 2005. The document also includes issues not directly found in the Beijing PFA such as marital rape, crimes committed in the name of honor and passion, racism, and racially motivated violence against women and girls, and calls for zero tolerance of such crimes. Progress is also noted with regard to the education and training of women, especially where sufficient political commitment and resources were present.

The outcomes document also places high on the agenda the signing and ratifying of the Optional Protocol to the Convention on the Elimination of All Forms of Discrimination against Women, adopted in 1999. In addition, measures are called for to address the challenges of the gender impacts of globalization, such as changing patterns of production and work and accelerated technological advances. Finally, the document reaffirms that the United Nations is making consistent efforts to incorporate a gender perspective and ensure the equal participation of women in its work.

Science and technology were addressed in only general ways in the outcomes document and explicitly mentioned only in the following three areas: women and the media, women and the environment, and the girl child. The document notes that media networks support women's groups, and that the Internet provides opportunities for women and girls to communicate better, enabling increasing numbers to share knowledge, network, and engage in electronic commerce activities. Conversely, a lack of computer literacy prevents some women from using the technologies. Some national policies and programs are noted that train women in natural resource management and environmental protection, and also preserve and use women's traditional ecological knowledge. Nevertheless, there appears to be little understanding of the differential impacts and 
implications of environmental problems for women and men. Obstacles to women's involvement in decisionmaking regarding the environment still remain. Noteworthy in regard to concern for the girl child is evidence of greater attendance in science and technology classes. However, factors that prevent young women from pursuing and completing their education and training also still remain.

The following statement - the strongest on science and technology in the outcomes document - articulates a major challenge that continues to affect the full implementation of the Beijing Declaration and PFA:

Science and technology, as fundamental components of development, are transforming patterns of production, contributing to the creation of jobs and new job classifications, and ways of working, and contributing to the establishment of a knowledge-based society. Technological change can bring new opportunities for all women in all fields, if they have equal access and adequate training. Women should also be actively involved in the definition, design, development, implementation and gender impact evaluation of policies related to these changes. Many women worldwide are yet to effectively use these new communications technologies for networking, advocacy, exchange of information, business, education, media consultation and e-commerce initiatives. For instance, millions of the poorest women and men still do not have access to and benefits from science and technology and are currently excluded from this new field and the opportunities in presents (United Nations 2000b).

\section{Summary}

The United Nations and other formal and informal women-supportive organizations have long documented the needs and concerns of women and have made recommendations that are benchmarks for the advancement of women worldwide. Women have articulated their concerns at official forums as well as through informal networks. As science and technology have advanced, so has evidence of a powerful connection between science and technology - and the concerns of women. A strong case for the role of science and technology in advancing women worldwide has been made in a least two key documents based on proceedings of landmark international events leading to and following the $1995 \mathrm{FWCW}$. Nevertheless, the compelling nature of that connection is not widely apparent among the world's women nor has it affected dramatically the decisions of policy makers worldwide. 


\section{Interviews with the Experts}

The second tool for gathering information useful to this study was the qualitative, focused interview. Openended interviews were conducted by telephone with women who were identified as respected experts in the field by those supporting this study, by other interviewees, or by their role in various formal, supportive organizations. These experts are seen as representatives of the many who have been deeply and consistently involved in this work. As a result, extensive interviews were conducted with 15 women. Appendix B lists the experts interviewed.

The interviews focused on whether a strong case can be made for science and technology as important and integral to women's advancement in each of the 12 critical areas of concern defined in the FWCW PFA, as summarized in Appendix A. ${ }^{2}$ In each interview, the following questions were discussed:

- Why are science and technology not emphasized more in the PFA and subsequent actions to support the advancement of women?

- In which of the 12 critical areas defined in Beijing are science and technology most helpful to women? Why would you recommend these particular areas?

- What compelling anecdotal example(s) can you suggest where science and technology have made a big difference in the lives of women globally or in a certain area of the world?

- What most important or key studies/evidence (literature/organizations) should be considered for this study? Can you provide material or citations?

- Who among the other experts on this topic do you suggest be interviewed?

The open-ended interview format encouraged the experts to explore their thoughts. Most brought up additional issues they believe are critical to a greater understanding of the role of science and technology in advancing the role of women in areas of women's concerns.

Reference is made to the beliefs and opinions of the experts whenever one or more of the experts expressed the ideas synthesized in this paper. The experts' opinions are remarkably similar. The descriptions included in this section are the synthesized views of the experts, not an interpretation. Each of the points made in the narrative is attributable to one or more of the experts.

\section{Why Science and Technology Have Not Yet Been Incorporated: The Views of the Experts}

Many of the experts described their views about why science and technology were not sufficiently incorporated into the PFA and why science and technology are still controversial topics five years after the Beijing Conference. A common theme is
I have listened to the naive belief that science and technology were tools for women's empowerment. It was impossible to have any of this represented in the final outcomes of the Beijing meeting. There is tremendous anger in the language and rhetoric.

- An expert interviewed

\footnotetext{
${ }^{2}$ Appendix A briefly summarizes the 12 critical areas, and the experts received this chart before the interview.
} 
the general tension between the developing and the developed world-between the world's "haves" and "have-nots" - although some experts believe the greatest skepticism is expressed by those claiming to represent the developing world's women rather than the women themselves. ${ }^{3}$

In the developed world, science and technology are accepted as critical engines for economic growth and improvements in the quality of life. This perception holds despite the fact that some groups consider certain impacts of technology to be negative. The experts agree, however, that even poor people in the developed world are better off in the material sense than poor people elsewhere. For example, those in developed nations often have access to washers, dryers, and refrigerators, and few live without electricity and phones.

The experts believe that, in the United States, science and technology have changed women's work over the past century in a significant and positive way. This has eased women's daily lives and has improved their quality of life by providing clean water at the turn of a spigot, simplifying housework through labor-saving devices, allowing easy shopping on the Internet, and increasing the lifespan of American women. Women now have a subjective sense of feeling physically better even while growing older, and the expectation that, if one is pregnant, one's child will be born alive and healthy and will live to maturity. This lifestyle is, in many ways, very high-level when compared with that of the rest of the world. Yet, the experts say, even in the United States, women do two-thirds of the child care because this is considered women's work.

The experts also note a cultural lag in keeping up with social changes resulting from the widespread use of science and technology. Some woman from developed countries might argue that the broad application of science and technology is destroying ethics. For example, with the prevalence of computers, children have access to pornography and other adult material with which they are not equipped to cope. From this viewpoint, women might have a demanding lifestyle with little discretionary time, as they simultaneously work outside the home, run a household, and rear children. Still, the experts observe that in the United States, for example, the economy is so influenced by high technology that gender distinctions, though present, are more subtle than they are in the developing world.

The experts also observe an ambivalence among people in the developing world about the quality of life enjoyed by people in the developed world. On the one hand, the Western lifestyle is a powerful and persuasive argument for women in developing countries on the potentially positive role of science and technology in their lives. For example, they like television, flying, and the power of reproductive choice. They view the Western lifestyle as desirable and want to experience the quality of life enjoyed in the developed world.

On the other hand, the very fact that science is acknowledged as the basis for the high quality of life and the dynamics of industrialized economies makes it seem a tool for oppression in the eyes of many in the developing world. The experts believe people in the developing world desire what the developed world already has in order to experience this quality of life and economic well being - which, ironically, is also perceived as giving the developed world power over developing countries. Although the developed world may view science as power for self-determination, the developing world may not see it that way.

In addition, the experts observe, women in the developing world tend to have a limited background in Western science, and they may believe it to be a negative force for their cultures and for women themselves. The experts note that many women in the developing world are "techno-phobic." They may believe science

\footnotetext{
${ }^{3}$ Disputes about the proper role of science are not limited to differences between the developed and developing world. Appendix E contains another example.
} 
and technology are male-dominated fields, and many believe a good deal of damage has been wrought by the application of science and technology, including high-technology wars and the destruction of the environment. One example is the dispute that erupted over the so-called "terminator technology." This dispute resulted when Monsanto Corporation sold women farmers in the developing world genetically engineered seeds for crops that last only one generation, so the women had to buy new seeds for the next growing season. Even though genetically engineered crops may increase crop yields, women farmers are accustomed to producing seed for the next year's crop rather than purchasing it. The experts say that the women farmers' perception is that Monsanto acted in its own interest at the expense of their interests.

One expert says that two "sides" exist with respect to science and technology. On one side are the organizations and programs discussed in the first part of this paper, such as the Gender, Science and Development Program, OFAN, and the Gender Advisory Board of the UN Commission on Science and Technology. These groups are "pro" science and technology and they form a network. On the other side are organizations that evolved from the anti-intellectual and women's movements of the 1960s. These groups also form a network. They exhibit distrust of the way science and technology have been developed. The expert says that the Women, Environment, and Development Organization has published strong negative critiques of military science, reproductive science, and environmental science. For example, with respect to reproductive health, the expert says that these women have concerns about such things as forced sterilization of poor women and the mentally disabled, imposition of birth control on people to reduce their birth rates, and upper classes trying to control reproductive functions in lower classes, all of which are viewed as misuse of reproductive science. The expert says these groups fear that human genome mapping and in vitro fertilization will be used to exploit women, and that surrogate-mother technology will also be misused. In fact, the expert says that these groups fear the misuse of science and technology in general. She says the movement focuses on how science and technology is misused and does not focus on any good flowing from them. ${ }^{4}$

Another expert notes that misuse of science and technology has resulted in contaminated water and land mines. In areas in Eastern Europe and Angola, oil fields that are not maintained properly are devastating the land. But technology can also be used to overcome some of these problems, the expert says, by diagnosing and documenting problems and mitigating or correcting adverse conditions.

One expert characterizes the current situation as two sides having difficulty making contact. The two sides tend to struggle about the appropriate positions to take. The expert says that the women's movement believes the developed countries are not "walking the talk" and the scientific community is not willing to say that no research should be done on fetal tissue. The expert says that "rational" decisions are needed, not "all-ornothing-at-all" decisions.

\footnotetext{
${ }^{4}$ One reviewer commented on the question: Why has there been so little progress, given the high intergovernmental profile the issue of women, science, and technology has received. The reviewer suggested that strong advocacy from women's groups may be working against acceptance by a sector that is primarily male. It may be better, the reviewer said, to mainstream the concerns, which are well known by now, into the operational level, rather than continuing to be so militant.
} 
Another facet of the developing world's resistance to Western science is that scientific issues are related to the issues of the particular country, such as its natural resources. Western science may overlook distinctions that are critically important to local populations in the developing world. ${ }^{5}$

Fundamental to the developing world's concern about, and resistance to, science and technology is their perception that their countries are being exploited by Western economies, the experts say. Some are suspicious of anything Western. For example, skeptics may feel that Western science tends to sweep aside the indigenous knowledge of the natural world as superstition. In some circles, for example, there is concern about "biopiracy." This is the idea that indigenous products for medicine in the developing world are being taken away by developedcountry scientists and patented by Western corporations. The issue of indigenous knowledge is especially important in pharmacological and health-related areas. Companies are trying to patent processes that rural people have used for a long time. In India and Thailand, for example, efforts are now under way to educate people to not give away their indigenous knowledge to anyone who inquires. Large corporations, rather than small businesses, are seen as the problem. The proper use of indigenous knowledge is for small-scale capitalism so that women can profit from the knowledge they have, the experts say. Key issues in development, then, are who will develop natural resources and who will control intellectual property rights.

Another issue the experts raise concerns the role of science itself. Public understanding of science is critical, in both the developed and developing world. Yet, one expert says science remains enigmatic to the public. The expert says the American Association of Engineering Societies commissioned a Harris poll on public knowledge of science and technology in the Unites States. The survey showed that the U.S. population is vague about the role of engineers, believing stereotypes (for example, that scientists and engineers develop weapons and blow up the world). The experts observe that there are few rewards for scientists who work with the public and, in fact, scientists' careers may suffer if they do so. The experts also observe that the Western scientific community itself has done little to help the situation. It has largely remained aloof and has not committed itself to the role it could play to help women around the world.

Related to this is the observation by one expert that such U.S. federal agencies as the U.S. Agency for International Development and the U.S. State Department once had scientific expertise on their staffs, but now they no longer do. The implication is that the diplomacy arm of the U.S. government has no scientific background, neither men nor women.

On the face of it, the experts say that women everywhere tend to be closed to science, mathematics, and technology, but this may be because these topics are presented to women as abstract and difficult. If science and technology were presented to women as providing simple solutions to real problems, the experts believe women would better grasp and embrace them. Simple ways of solving problems using technology that has been known for years or even decades could be quite helpful to women in developing countries. For example, an expert says local people may need to clean their water wells; young graduate engineers, using simple technology, can teach them how to do that.

\footnotetext{
${ }^{5}$ One expert believes that perceptions of the potential role for science and technology in the 12 critical areas vary so significantly between the developed and developing countries that there might need to be two papers to adequately cover the topic — one written by developed-country analysts and another by developing-country analysts.
} 


\section{Why Science and Technology Are Important}

As one expert says: "Aren't we in the business of changing the world?" Implicit in the actions recommended in the PFA is the notion of social change. Women the world over want to see advancement in areas they define as crucial to their well-being. Although various ethnic groups are viewed as critical underserved population groups in different countries, women are the one population seen as a critical population worldwide.

The experts believe the argument for science and technology as tools for change should be built as an argument about the nature of social change. Do women want change? What have been the major vehiclesthe drivers - of change? The experts believe that science and technology have been the engines of profound social change. Examples they cite are the printing press, weaving looms, and the computer. When explained in this way, the experts believe that women will see the truth in the argument that science and technology drive change. The experts believe that, rather than making these simply women's issues, science and technology should be part of broad developmental issues. The tragedy is that, when women are excluded from scientific and technological training, they also tend to think of themselves as marginalized and to behave accordingly. The experts view alienation and poverty as issues of underdevelopment.

The experts also view science and technology as "here to stay"-science and technology are seen as given - and their impact cannot be reduced, even if some women want them to be. Women everywhere may believe they have more important problems to solve than gaining education in science and mathematics which ultimately fosters economic development. Yet, experts say women must become involved if they are to have input into the manner in which science and technology are used and if societies are to benefit from the insights and knowledge that women possess.

The experts say part of making a compelling case that science and technology are crucial in women's advancement lies in making arguments that are compelling to governments around the world because governments have to effect social, political, and legal change. One expert says: "It's not enough for the United Nations or other organizations to favor women's involvement in science and technology. [Social, political, and legal] change is needed at both the local and national levels." This expert says: "Tell governments that the practical outcomes of science and technology are not value-free and the more their people participate in science and technology, the more positive the outcomes will be for their countries."

The experts point out that the definition and expression of important issues at Beijing and the context for solutions to problems have focused primarily on political change within repressive social structures. The tools of change emphasized most are education and law. Many lawyers participating in the Beijing conference emphasized moving forward slowly and taking a moderate approach to improving the rights of women using the law as a tool. One expert says that perhaps science and technology have not been emphasized more because, globally, women tend not to use the vocabulary of science and technology and tend not to see science and technology operating in their own lives. In contrast, women trained in Western science have a vocabulary to use for change in the world around them. Another expert says that power 
resides not only in political institutions, but also in industry - "industry funds the politicians"-and that science and technology provide strategies that drive the whole socioeconomic system. Nevertheless, the experts also believe that science and technology imposed from outside the community do not empower local people.

Women are making progress in gaining equal status in the United States; the experts note that women have better incomes and more decision-making power than they had formerly. Further, because social change takes decades, patience could be a key virtue when considering issues of equality. Solution to the problems of inequality will not be found rapidly. An expert notes that perspective is needed on women's progress. Women have had the vote for approximately three generations in the United States - not a long period by historical standards. Yet significant change in women's roles has been achieved, partly because of developments in science and technology. Today, gender equity is closer than it has ever been in the United States, but further change may take several more generations to achieve.

The experts also discuss the "leapfrog" notion in social change. The leapfrog idea is that the developing world can skip some of the developed world's developmental processes, leaving out some steps and getting further along by skipping those steps. The developed world in effect is saying, "Look at our example and see if you can do better." One expert says the leapfrog idea should not be based on unquestioning adoption of Western technology. One example the experts cite is the development of ineffective woodstoves without asking women for their insights and preferences. The experts believe that women in developing countries should question the appropriateness of Western science and technology in solving local problems. The experts note that in cultures without telephone infrastructures, for example, wireless technology could be more suitable than installing wires. Wires would mean a huge economic investment and could cause environmental disturbances. The experts say that certain technologies appear to be especially appropriate for leapfrogging and that wireless communications is one of them.

The experts also note that a good deal of international discussion on development focuses on how to incorporate science and technology into international development efforts. Institutions of higher learning tend to stress their own country's or region's strengths. For example, India has built on excellence in mathematics to improve its capabilities in computational science and software. Japan has sent many students to U.S. graduate education programs and has adapted imported science and technology to fit local needs. Discussed frequently in international forums are such issues as whether markets should be free or controlled, scientific institutions should have academic freedom, banks should be centralized, and political institutions should be more democratic. Science and technology are a major parts of these discussions. The underlying, pervasive question is whether the receiver or the giver of funds for development should be in control.

\section{Women's Roles}

Relatively few women have careers in science, the experts point out. Yet, science and technology offer many possibilities for improving women's situations. One expert says: "My notion of women

The impact of women on scientific discourse may give us another perspective on the doing of science.

- An expert interviewed in science and technology includes them as creators, appliers, and users of knowledge - and as innovators - more than just producers of knowledge. They can bring things together in new ways, not just perform laboratory science." 
The experts point out that many women serve in support roles for science and technology as administrative assistants, research assistants, and technicians. These women are making important contributions, yet their roles are not often recognized by scientists and their institutions. ${ }^{6}$

Many people pursue but do not use science, an expert says. A mistake made in Western science is thinking of scientists and engineers as producers, but not users, of knowledge. For example, the United States Department of Agriculture employs women using knowledge on a daily basis as food inspectors and veterinarians specializing in animal health. Even though they work in science and technology, these women face problems of recruitment, retention, and advancement in their careers. Women in computing have these same issues. People who perform research represent only a small fraction of the overall impact of science and technology on society. Many more women are needed who can be comfortable with and use science and technology in a variety of applications.

Another expert says that men and women scientists would be expected to contribute equally on a daily basis, but individuals have different perspectives. There are even differences in overall perspective among women and between women and men.

Sometimes international conferences on gender equity ignore the basic, fundamental needs of women. Instead, they focus on the "glass ceiling" and how to get women into management. The experts believe that the international community must pay more attention to women's basic needs, such as adequate food, shelter, medical care, safety, and education.

The argument runs that women have the obligation to see that science and technology are used in beneficial rather than in destructive ways. This is a key point - the way in which science and technology should be institutionalized. This would focus the role of science and technology in solving women's issues by women in science and technology within agencies that work to see these

Science and technology impacts on the advancement of women and the impacts of women on science and technology are totally interrelated.

- An expert interviewed disciplines used in their own countries and internationally. The experts say that this could occur because women may be more interested in ethics than are men. Women becoming more involved in science and technology could mean that science and technology is used more often for constructive purposes than for destructive purposes.

Another critical argument is the "brainpower" issue, experts say. The United States has made significant progress in involving women in science and technology, but the issue of excluding one-half of the population in any country is significant, because each country needs its best minds focused on science and technology. Vast potential could remain untapped because women have not received the guidance and training to even consider participating in science and technology or applying them in a variety of fields. This is considered an enormous, global issue that holds across all countries. When women are excluded from science and technology in any culture, that culture is bereft of half of its talent and ability to solve social problems and improve its people's quality of life. The experts point out that large corporations are also becoming

\footnotetext{
${ }^{6}$ One reviewer commented that there are two levels of interest of women in science and technology: (1) all women need to have an understanding of the basic science of things affecting their lives, and (2) fewer women need in-depth knowledge of science and technology to use as professionals.
} 
concerned because demographically there are not enough men to fill the jobs that are already available, let alone those that will be available in the future.

The industrial revolution and subsequent advances in technology have allowed machines to do work that once required human strength, the experts observe. Though most women lack men's upper body strength, machines are effective equalizers, and great advances in women's roles were made during World War II. Women could work in factories that opened up jobs for them, and factory jobs paid better than "female" jobs. For example, the phenomenon of "Rosie the Riveter" in the United States during World War II-when women took their children to day nurseries and worked in airplane factories riveting fighter aircraft — helped to empower American women. The experts say that these experiences made U.S. women think more deeply about their contributions because they had been empowered during the war.

The experts note that women made significant progress during the $20^{\text {th }}$ century. One expert reports that when she started her engineering education, there was almost no place for her to go to school. Now, she notes, many professionals are concerned about and actively working on recruiting more women into science and technology and many more schools are available to women.

The experts also note, however, that the feminization of occupations appears to have an unintended consequence - a reduction in the status of the occupation. Where women dominate a profession, it is often viewed as less valuable. One expert cites data tracking the percentages of civilian jobs filled by women; the data show average lower pay for women than men. The fundamental reason appears to be the perception that men are better suited to more important work. This is a function of the perceived proper role of the sexes - expectations differ by gender.

In Russia, Egypt, and the Philippines, for example, doctors tend to be women, the experts point out, and the profession is considered to have an inferior status. In fact, doctors now tend to be women everywhere, and more than half of medical school enrollments in the United States are women. Although professional status declines when women are in the majority, the eventual result could be gender equalization of the professions. The experts report that the American Psychological Association has expressed concern about the risk that the feminization of science could be linked with the loss of status for women-dominated fields. This lower prestige can lead to lower salary earnings, as well.

For example, the experts note that, in the for 15 years before 1996, half of new Ph.D.'s for U.S. women were in the social and behavioral sciences; there were relatively fewer in the "hard" disciplines of physics, chemistry, mathematics, and engineering. The experts say that women might be more interested in the content of social and behavioral science. Yet, the experts say that governments seem to favor "hard" science — which is associated with men's expertise — over "soft" science — which is associated with women's. One expert thinks this could be because governments are made up chiefly of men.

\section{Women in Science}

The experts note that younger women look at the great difficulties older women have undergone in their careers and are saying they do not want to go through what the older ones have. The importance of the involvement of older women to society, as well as personal benefits to them, should be
Women scientists might not ally themselves with feminist approaches because they feel they could jeopardize their positions in science if they do so. So, the feminist groups exhibit a distrust of women in science and the women in science distrust the feminist groups. . . IIt's a culture clash.

- An expert interviewed 
communicated to younger women, the experts say. These are benefits that counterbalance the enormous sacrifices women have made for the progress of women.

For example, experts say that many women may work in science because they enjoy it. They often do not focus on barriers, but move forward, working around the barriers. It is only later in their careers that women realize they have experienced subtle and cumulative discrimination. They discover they were isolated from critically important networks and their salaries and the size of their grants were comparably lower. There appear to be two ways in which women can respond: (1) they can aggressively "make loud noises" that are not well received, or (2) they can deny the impacts of discrimination on their careers and on themselves.

The experts comment that some women scientists disassociate themselves from women's issues because they want to be real scientists and real engineers. These women want to earn their ways according to the same rules that men have and they tend to oppose women's groups and women's issues. Other women, perhaps more advanced in their careers, speak out about their experiences as women in science and technology. As these women become more secure, they have fewer problems becoming involved in women's issues.

One expert observes, "We are not asking for women scientists to be militant, but for the sake of making the case that women's professional involvement in science and technology is good for them and is good for issues that are important for their societies, women scientists need to get involved. They need to make a statement of opportunities, not necessarily 'go out and fight."'

\section{Men's Perspectives}

The experts do not comment extensively on men's perspectives. However, a few comments on male roles are made. For example, one expert says that, if access to production and use of science and technology are viewed as important by men, then women around the world need to pay attention and become involved if they are not to be marginalized.

Several experts describe men's views as a concern. One expert says, "We have to get past the men." Men make important decisions, such as irrigation methods, yet more women are actually the farmers. Or, in education programs, men have to agree that women can get the education they need in science and technology, and men may oppose their involvement. The experts say that NGOs often make no attempt to get past the men. They may go to a village and, under the rubric of local participation, listen to men who say, "Give us big irrigation projects," or ask for cash crops rather than crops that yield food to the people of their villages. A village chief might develop these projects, surrounding himself with money and power. Other villagers become more beholden to him. Eventually, many of these projects fail, because they do not benefit from the participation of the women. The experts say that men have power to oppose women's involvement in projects, and it is often a delicate matter to obtain men's approval of a project involving women.

An expert cites an example. A business in a developing country gave women workers paid time off to go to family planning clinics. The men got upset because this was seen as interfering with their reproductive prerogatives. At first, the women thought the family-planning concept was strange, but gradually they quietly conspired to go to family planning. The women learned about birth control and began to practice it. The fertility rate dropped, and after a time, pregnancies became more rare. Eventually, the men gradually and grudgingly came to accept family planning. At first, they were taking bets about how long this would last. But they came to respect the effort as important. Now the sexes have a peaceful coexistence. But, the expert says, it took a long time. 


\section{The Experts' Comments on the 12 Critical Areas}

The experts tend to say the 12 critical areas ${ }^{7}$ overlap substantially and it is difficult for them to select the ones most relevant to science and technology. However, the areas they mention most frequently, and those receiving the greatest number of comments, are education and training, health, economy, and communications. Several other experts mention areas in which the theme is empowering women through, for example, decreases in violence and improvements in institutional mechanisms, increased access to power, and greater human rights. The girl-child is seen as important and as crosscutting other areas, but is not mentioned in the top four chosen by any of the experts.

One expert says: "You need to develop an understanding of grouping these 12 critical areas." Often, several areas of concern appear to be interrelated and interdependent in their ability to be affected by science and technology and to advance the status of women, the experts say. For example, the science and technology of energy production and use is related to the support needed for many women's activities around the world. Off-grid energy applications, for instance, can provide power for cellular phones and computers - wireless communications that can leapfrog over the wired infrastructure common in the developed world but lacking in many developing countries. These communications technologies can help bridge the "digital divide" that separates those with and without access to the Internet. With wireless communications, producers in rural communities can market goods directly, find out prices so they know when to bring goods to city markets, establish local communications enterprises, and transmit health, environment, and education information necessary to the well-being of women's and their families. Women thus have an opportunity to receive and send information, potentially transforming their self-perception as persons capable of initiating messages important to others. The experts say that although barriers to such scenarios are significant, they must be overcome.

Other examples of the interrelationship of two or more critical areas of concern are given, as well. For example, one expert views health, violence, and armed conflict as integrated issues. Another sees economy, decision-making, and institutional mechanisms as interrelated.

Science and technology are not critical areas in their own right, according to the experts. Instead, they should be viewed and used as crosscutting tools to deal with the 12 critical areas. The experts believe the common theme underlying the 12 critical areas - the fundamental physical safety, integrity, and well-being of women and children - can certainly be supported by science and technology. The experts comment that, rather than casting the critical issues in a negative light, we should cast the issues in a positive light, focusing on why women should participate in or benefit from science and technology.

\section{The Top Four Critical Areas Identified by the Experts Interviewed}

The experts discuss the reasons for their selections of the "top four" critical areas for their potential relevance to women and science and technology. The following description of their comments is presented in order

\footnotetext{
${ }^{7}$ Appendix A lists the 12 critical areas and defines them briefly.
} 
of emphasis across the interview material taken together, beginning with the topics receiving the most comment and progressing to those receiving the least.

Responses to the critical selection of the top four areas may have been influenced by the summary chart on the 12 critical areas presented in Appendix A. Therefore, as each critical area is identified, the brief summary of the problems listed in the summary chart is shown in italics.

Education and Training. Discrimination by gender exists for women in education and training, especially vocational training, training in science and technology, and continuing education; women have a higher illiteracy rate than men.

The main objective is to get women into science and technology.

The experts say that science and technology education is lacking among women, especially women in developing countries. For example, there are no engineering schools in the developing world. This lack of education and training hampers countries' abilities to develop a quality workforce, because they are not training one-half of their brainpower pool. They say that even in countries in which women are receiving degrees (such as Taiwan, Russia, Korea, India, and Egypt) women often cannot get positions because legislation against discrimination in hiring and promotion is lacking. In Egypt, for example, advertisements for positions state publicly that "only men need apply." The experts believe that addressing the complex issues in the developing world requires the best minds of both men and women.

Even in the developed countries, education and training seem related to the status of women. The experts say that in the United States, girls are still not being encouraged in mathematics and science in the elementary grades. National statistics for the United States show that $40 \%$ of life science undergraduate majors, $18 \%$ of engineering majors, and $10 \%$ of graduate students and faculty in engineering are women, according to the experts. The Taliban in Afghanistan has banned the education of girls altogether, and in India, most girls receive only three years of education. They say that in the United States, young women do not have many role models at the high-school level when career decisions are being made. Parents and teachers steer women away from those careers, the experts say. At the undergraduate level, the choice of majors appears to depend on how women perceive themselves. The "hard" sciences and mathematics lose one-half of majoring female students in the first year. Women appear to see these subjects as too difficult and demanding and the environment as too competitive.

The education of a woman is critical to the well-being of many people beyond herself. The experts note that research shows the education of women has a tremendous positive impact by decreasing the birth rate. Decreased poverty, improved economic sustainability, and better quality of family life are correlates of the mother's educational level.

Literacy itself is viewed as critical; the printed word is needed for science and technology communications and for Internet and email use. Training in mathematics is seen as particularly important. The experts say that education is needed in literacy and numeracy. They point out that the World Bank focus is primarily literacy — being able to read, but not numeracy — being able to figure. The experts agree that algebra should be required of everyone because it appears to be a "gatekeeper" course in terms of women's careers. In addition, basic training in mathematics is essential in managing business enterprises. 
Scientific literacy is also seen as critical, and scientific training is seen by the experts as contributing to objectivity of the thought stream. Young girls and women should be able to interact with the world and to ask "What if I . . .?" questions. The experts say that this gives them a sense of power and authority. Education is seen as an engine that drives preparation, stimulation of interest, and competencies.

Women also need business training along with specialized skills and information on how to organize themselves, produce food, apply physical technology, provide proper nutrition, and foster cleanliness. The experts say that there is also a need for "affirmative action" programs in science and technology training for women in order that women receive enough training to use technology. Training women in science, mathematics, and technology to train other women could be an effective approach, the experts say, although there are issues of cost and access to technology. Because of new communications technology, women can gain access to educational opportunities never before imagined. The experts say that the education of girls is particularly important, because it opens the door to countless opportunities.

Education and training are also key to adequate preparation and the competence needed to enter decisionmaking and leadership positions, the experts agree. Lifelong education and training are central to more technological and scientific literacy in the population at large. Education and training are fundamentally important to sustain interest in and curiosity about science and technology, but also to achieve a more scientific and technologically informed citizenry which the experts believe to be a higher quality citizenry.

Also, the experts believe that, when people learn more, they are more apt to see and accept all humans as they are, respecting the diversity among peoples and cultures. This relates closely to human rights, they say. Greater education is seen as resulting in people being less inclined to make invidious distinctions or to foster divisive issues. Scientific literacy, and an everyday understanding of basic scientific precepts, help people respond as an informed citizenry in their own lives and in their society. The experts say that basic scientific understanding allows people to decide between beneficial and destructive applications of technology and equips women to make better personal choices on such issues as birth control. If women have scientific and technical knowledge, they acquire the power to decide, to set research agendas, to be in control, and to apply such knowledge in their own lives.

The scientific approach leads to questioning rather than accepting things on faith alone. Women in the developing world need to be able to understand their indigenous knowledge and to evaluate Western science and new technology within their own cultural contexts. The experts say that education and training help them do this.

Although many nations recognize a fundamental need for improved education and training, one expert observes that they infrequently make the policy connection between this need and increasing the participation of women in science and technology fields. This expert says policy makers should realize that increasing the diversity of their science and technology workforces through the participation of women can enhance the quality of science, equity, and each nation's economy. 
Health. Discrimination by gender exists in access to quality health care and health information; unequal relations exist in matters of sexual relations and reproduction.

Access to health care is probably women's greatest need. Women in developing countries lack access to health care, and their life expectancy is shorter than that of women in the developed world, the experts say. Birth control is an enormous issue in developing countries. New and re-emerging diseases, such as tuberculosis and cholera, call for worldwide medical action. Safe drinking water can make a tremendously positive impact on the health of people in the developing world.

One expert says that nutrition is a critically important area related to health. Because of science, we now understand the critical importance of Vitamin A in, for example, preventing immune system problems and blindness. The U.S. Agency for International Development is developing a strain of rice with a high Vitamin A content, which will enhance the immune system. This could also help the fight against AIDS transmission in areas of the world where rice is a staple of the diet.

Extension agents have promoted the use of fertilizer. The appropriate use of fertilizer leads to increased crop production. ${ }^{8}$ Although the green revolution provided many benefits, it also caused unintended negative consequences. For example, the use of pesticides such as DDT and herbicides led to environmental damage and negatively affected health in the United States.

The experts consider water to be a critical area for scientific and technical intervention in the developing world. Simple tests for water quality could be made available. The experts note that adults in the developing world can be treated as adults everywhere rather than as children who lack sophistication. In other words, government programs do not have to decide for them. In general, the experts say that developing countries need knowledge and expertise to be melded - to blend Western knowledge and indigenous knowledge-for the best outcomes. Women in the developing world need to understand, for example, the importance to health of basic sanitation and hand washing.

The experts agree that science and technology can help if they are used at an appropriate level. For example, when villages in the Andes had insufficient water, "mist nets" were set up along ridges and water vapor condensed on the nets. The nets caught tens of thousands of gallons of clean water. This "low" technology was a highly creative, helpful, but not obvious, solution. In another example, in rural areas in Africa (such as Lodwar in Kenya), windmill technology is used to pump water. This has eased women's lives enormously because it brings more reliable water supplies closer to their homes and allows them to farm. Another good example is the project in Nigeria reported in Appendix D.

The experts also note a disturbing trends in acquired immune deficiency (AIDS) which is widespread in subSaharan Africa. Men with AIDS are raping women as a way of killing political opponents, which appears to have been the case recently in Zimbabwe. Thus, rape is being used as a weapon of war. AIDS is spreading in Eastern Europe as well. Health and violence are closely linked issues, as are health and

\footnotetext{
${ }^{8}$ One reviewer commented that people in developing countries used fertilizers before extension agents came into being. Many people believe that artificial fertilizers have done a good deal of environmental damage and added to farmers' costs.
} 
reproductive issues. Health is also an issue in such cultural practices as female genital mutilation (which is linked with the critical area of the girl-child).

These are examples of key contributions of science and technology to women's health, as described by the experts interviewed:

- Vaccines and basic sanitation have combated diarrhea and respiratory diseases among children in the developing world. Vaccines for smallpox, polio, and malaria are now administered all over the world. In the United States, swamps were drained to defeat cholera and yellow fever. Now, new techniques to defeat these diseases can be used in the developing world. Research is needed in developing countries in this time and in their place.

- Antibiotics and other drugs for medical treatment are a science and technology breakthrough. The cutting edge is "combinatorial chemistry," which investigates how to link indigenous knowledge with Western science and technology, such as through the Fogarty International Cooperative Biodiversity Program.

- Among other AIDS education efforts, African government officials are visiting towns to inform people that AIDS is, in fact, a serious disease and not a form of bewitchment, as many in African countries believe. The government ministers are conveying scientific facts, such as how people caf avert AIDS and protect themselves, how AIDS is spread, and so on. Science and technology can assist women in combating the AIDS epidemic. A third of those suffering from AIDS worldwide are women. ${ }^{9}$

- Before women moved into leadership positions at the National Institutes of Health (NIH), health studies on women were virtually nonexistent; for example, cancer and heart disease studies were based largely on male samples.

- While contraception created a sexual revolution in the United States, control of the reproductive system is key to the advancement of all women. Historically, women used barrier methods, but modern birth control is an "incredible advance" that results in reduced birth rates, increased education for women, and better health and nutrition for children. However, U.S. policies affect women outside the United States when it threatens to withhold aid for birth control and abortions. Women need assistance because reproductive choice fundamentally affect their opportunities and life chances.

The experts note that the availability of energy is also important because it allows women to devote less time to subsistence-level activities - such as gathering wood and hauling water - that have negative effects on their health. When energy is available, women's time is more free for other economic activities and for child-rearing. Solar energy can also be used for to purify water in rural villages. (See Appendix D for examples of the contributions of science and technology related to energy, water, and health.)

The experts say that involving both men and women in health care delivery provides services to more people more efficiently, at less cost. According to the experts, the more women that are involved, the better the field of medicine will be, and the more people who will be treated.

\footnotetext{
${ }^{9}$ A reviewer said that in Africa, human immunodeficiency virus ( HIV) and AIDS affect four times as many females as males, contradicting the figure provided by the expert interviewed.
} 
Some harmful organisms are becoming resistant to drugs, an expert notes. With respect to health and sanitation, a concern is emerging in the scientific community that populations may be "too clean." That is, the human immune system evolved to cope with an onslaught of microbes, but, in the developed world, people are no longer exposed to these microbes as much as they used to be. Current scientific thinking is that these microbes serve to prime the immune system to deal with other, "very nasty" microbes. Some studies indicate that diseases like asthma are the result of the body turning against itself the mechanism it formerly turned against these other microbes. Scientists are now working to discover the optimal balance in exposure to microbes.

Scientists are now going to the developing world to look for the indigenous knowledge that Western science has lost. International cooperative biodiversity programs for bioprospecting are designed to involve people in the developing world. One expert says: "We have to go back to the people with the traditional knowledge of medicine and find out what they know. We work on combinatorial chemistry to see how things work together, rather than using a 'shotgun' approach. For example, we found Taxol from the yew tree. We've lost our traditional knowledge and we are trying to find it again."

In the United States, until about 20 years ago health studies on women were nonexistent, experts agree. Yet women comprise $52 \%$ of the population. Studies on cancer, heart disease, and other major diseases were all based on male samples. This issue was highlighted some years ago after a Harvard study on the use of aspirin to reduce the risk of heart disease had used 22,000 male physicians as its sample. There was a subsequent outcry about leaving women out of such health studies. The Office of Research on Women's Health at the NIH was established as a result.

The experts point out that women's bodies are more complicated than men's bodies; therefore, medical researchers had used the men's bodies in their sample to be more efficient. Men differ from women in metabolism, fat thickness, skin, and other ways. Also, children have different physical processes - they are not smaller adults. Scientists now understand that women and children need to be included in medical studies.

After a woman took over leadership of the NIH, U.S. health studies started using women in their samples, and research began to include new breast cancer and menopause studies. Women began to be included in heart disease study samples. When medical research was begun on women's health issues, many examples were documented of the ways women react to medicines differently than men do. Genetic markers for breast cancer have been identified. Women scientists developed the imaging now used to diagnose breast cancer.

Economy. Discrimination by gender exists against women in hiring, remuneration, promotion, working conditions, access to productive resources, and sharing of family responsibilities.

Several experts define economy as "the most crucial" critical area. Economy is seen as the most The economy is the single most important area. Women must be trained for participation in the workforce.

obvious area in which to work against discrimination against women and to give women the capabilities and tools that they and their nations need. In the Western world, science and technology drive almost everything (e.g., telecommunications, transport, production, finance, and so on) having to do with the economy. The experts also view education as critically related to economic development. 
Everyone needs financial resources. But in the developing world, there are virtually no jobs available; unemployment is a grave problem, the experts say. As a result, people tend to be self employed. Women thus need to be empowered in the ways they can make money. Today, many women are being left by men to fend for themselves and their children in rural areas. Increasing numbers of rural men move to cities. This rural-to-urban migration leads to the growth of shanty towns in such urban areas as Nairobi, Kenya; Lagos, Nigeria; Addis Ababa, Ethiopia; and Harare, Zimbabwe. Squatters are living in makeshift cardboard structures. Men are living alone or with a new woman they have found in the city. The men want to be part of the cash economy, which leads them to take jobs as casual laborers. For example, a man might earn 50 cents for laying bricks one day a week.

The experts say that many men would be better off back in the villages. A current policy trend is to decentralize the activities of the capital cities in the developing world so that each region has a city where commerce and government are conducted. ${ }^{10}$ For example, Tanzania and Nigeria have both moved their capital cities. The experts add that women disproportionately bear the brunt of a poor economy. Decentralizing might be a mechanism for helping women. For example, if women have produce, they can sell it to markets in the nearest towns. It would be easier for them to transport their goods to nearby markets than to remote cities. Increased avenues for selling women's crafts, agricultural products, and other goods in a nearby urban area would help women. Women also typically provide cooking services for construction projects around the world. Men purchase the meals or, more commonly, the major contractor pays for meals for the workers during construction, and the women earn money this way. More construction means more opportunities for women.

The experts say that if women start achieving some success in science and technology leadership, they will be much harder to ignore. When women have leadership, this affects every economy. Leadership is attained through training women in science and technology. Technology-trained people are data-oriented - they know how to build a compelling case using data. And engineers are in great demand in the financial world because of the impact of science and technology on financial activities. In fact, all areas of the economy require leadership in science and technology. Women themselves will bring attention to gender discrimination and change will come.

Formerly, the experts point out, corporate personnel policy changes regarding women were motivated in large measure by compassion, but this has recently changed to bottom-line profits. Corporations are developing programs to get girls and minorities involved, because the number of white males for the work force is shrinking. Girls and minorities are needed if corporations are to fill high-quality technical jobs. It is in industry's self-interest to focus on women's advancement, mentoring, promotion, and networking. Once women have a background in science and technology, companies worldwide value them. The experts say that a critical mass of women is needed, however. Token women will not be enough to effect change, because the token woman has to perform her job and plow new ground for other women. Because this is quite difficult, the desired result takes too long to achieve.

Balancing career and family did not become an issue until women started becoming successful in the business and professional worlds. Experts say that women experience discrimination by gender in hiring, remuneration, and promotion, and that women in scientific and technical careers experience this same discrimination.

${ }^{10}$ This follows on the pattern of decentralization found in the United States, where activities are scattered all over the country (e.g., New York, Chicago, Washington, and San Francisco, which are hundreds to thousands of miles apart). This decentralization is made possible by a sophisticated system of transport and communications. 
The experts agree that women need to be equal partners in the economy in all the critical areas. If women are equal, then the other critical areas tend to fall into place. For example, if women participate as full members in the economy, their participation will help create wealth and move families out of poverty.

Communications/Media. In most countries, the media project a negative and degrading image of women (i.e., often violent and pornographic); women rarely reach media power positions.

The experts view the Internet as an incredible example of developed-country science and technology helping the developing world, with important repercussions in the lives of women. The experts say that wireless communications are a remarkable example, because women in developing countries enthusiastically embrace them. Wireless information transmission generally will be a powerful tool for economies and education in rural areas, particularly for women. ${ }^{11}$

The experts view the future of the media as driven by training in information technology. Women trained in information technology will have an impact on media representations of women. Women engineers, women camera people, and technically astute women journalists will influence how women are portrayed in the media, and as well as how women are seen and see themselves.

The experts say that women need to move away from the subsistence level of economic activities (such as making small batches of jams and jellies) to a level in which they run more substantial, "transformative" businesses from their homes. Using communications technologies and working from home, women can run businesses with the world as their markets, through satellite technologies supporting wireless Internet communications.

The experts point out that in rural parts of the world without electricity, the use of wind-up radios to increase the availability of information can at least expose women to information that they would otherwise never receive. Interactive communications, such as cellphones and the Internet, are even more powerful tools in the advancement of women. There is great power in being able to get one's message out, the experts say.

One expert gives an example of the value of communications technology. In Northern Kenya-a very remote area-rural villages use cellphones to call townspeople to find out prices of goats and to decide when to bring herds to market to get the best price. Before the advent of the cellphone, women farmers had a more difficult time receiving market information. Now, farmers can maximize their profits.

The experts say that, in the developing world, women's microenterprises (small businesses) produce an array of goods such as handicrafts, woven cloth, clothing, ceramics, baked goods, and agricultural products. Yet, women have limited means of marketing their products to the world. They must rely instead on brokers who buy their goods at depressed local prices and sell them to customers in affluent countries. If women microentrepreneurs had access to communications technology, they could avoid brokers and market their

\footnotetext{
${ }^{11}$ Appendix D presents information on the Acacia Project, which is designed to promote the use of information and communications primarily among mostly illiterate women in the developing world.
} 
products directly. But women in the developing world have little or no access to modern forms of communication such as cellphones and the Internet.

Part of the difficulty lies in the lack of means to acquire these technological innovations, and part lies in women's inability to use written forms of communication because of high illiteracy rates. Another fundamental barrier to women's use of this equipment is the lack of electricity. Yet another barrier is lack of telephone and cable lines. In a world where two billion people live without electricity, and the cost makes extending electric utility lines prohibitive, what opportunity do these women have to participate in modern forms of communication and marketing? ${ }^{12}$

The experts assert that technology can provide part of the answer. Bringing electricity to rural areas through distributed power, including generation of electricity from renewable energy resources such as solar cells (photovoltaics, or PV) and wind power, can provide a means to power cellphone and computer technologies in developing countries. Satellite technology provides wireless communication capabilities and will soon be available worldwide. PV-powered computers will be able to communicate on the Internet via satellite communications.

The experts point out that communications among women on topics of interest to women are supported by the Internet and email. Connections are established through listservers and other mechanisms. Email can focus on personal relationships and shared information about daily life.

What does this mean for the advancement of women? Women will need education and training to be able to use technology. They will need a shipping infrastructure to be able to deliver their goods to world markets. But most important, their vision of themselves - as more than passive recipients of information-will be transformed, say the experts. They will see themselves as providers of information and initiators of messages that give them a voice at home and abroad.

Communications technology can also be used to reduce violence against women in the world, the experts say. For example, a listserver ${ }^{13}$ shares information and strategies around the world about violence against women, raising awareness that women are not alone in their cultures and villages in dealing with this ubiquitous problem. Information is shared, for example, on Peruvian legislation on divorce, child labor in India, and violence and women in Uganda.

The experts say that wireless communications also have a political impact and support democratization. There are democratizing implications of two-way public access to information for hierarchical power structures that rely on access to knowledge. The oppressed will know more and will get their messages out. Governments have so far had only limited success in attempts to censor the Web. The Internet is less controllable than are schools, and it also allows direct access to education. The Internet affords a way for women to organize, which will ultimately have a political effect. The experts believe that the Internet can facilitate democracy because information is power. The experts say that the digital divide (some have access to the Internet and some do not) can and should be addressed. For example, in the United States, $\$ 100$ million was earmarked to make computers available to children in Mississippi.

\footnotetext{
${ }^{12}$ Two reviewers noted that their experience and documented evidence show that only a small proportion of women globally have or are likely to have access to the Internet because of physical barriers (such as lack of electricity, computers and phones), and perhaps more important, intellectual barriers (such as illiteracy).

${ }^{13}$ Endviolenceagainstwomen. See also end-violence-mod@edc-cit.org.
} 


\section{Comments on the Other Critical Areas}

The remaining eight critical areas receive less emphasis; the experts make fewer comments on them. Nevertheless, all the critical areas are considered important. The experts find it more difficult to draw the linkages between science and technology and the advancement of women in violence, the environment, institutional mechanisms, decision-making, poverty, human rights, the girl-child, and armed conflict.

Technology can help document the abuse of women and can help in the prosecution of violence, say the experts. Examples include using DNA evidence to prove guilt in rape cases and disseminating information on the Internet about instances of violence against women.

Violence. Women are more subject than men to physical, sexual, and psychological abuse at home, in communities, and in the workplace; they suffer from systematic violence during war. $^{14}$

Health research could help to reduce violence when it aids in identifying situations in which women are abused but are afraid to report it because of possible repercussions. Science and technology can play a diagnostic role. In addition, communications technology can be used to disseminate information about the nature,

In India, women are burned because their dowry isn't large enough. It's called "bride burning." Suttee, a practice in which widows throw themselves on their husbands' funeral pyres, though outlawed, is still practiced. In Brazil, women are killed because their husbands accuse them of being unfaithful, and the legal system permits them to get away with murder. In the Mideast is purdah and the beating of women. In Kosovo, rape is common.

- An expert interviewed extent, and location of violence against women.

Indirectly, to the extent that women's involvement in science and technology empowers them, they become less easy targets for violence. Some of the experts believe groups opposed to violence against women tend to be reactive in their approaches, for example, wanting society to tell men to stop being violent. But in much of the world, violence against women is accepted because women are powerless and are considered their husbands' property. In this view, when women are more equal partners in the economy, their contributions will be more valued and they will be safer from attack. Women will also be more able to afford legal counsel.

Environment. The deterioration of the environment and depletion of natural resources negatively affects the health and well-being of girls and women differently from boys and men.

Science and engineering have a strong impact in the area of the environment, the experts say. The disciplines that particularly affect the environment are the life sciences and explicit environmental sciences, such as biology. These disciplines are
The fields of engineering with almost $50 \%$ women are biotechnology engineering, bioengineering, and environmental engineering. In these fields of engineering, women combine their desire to help society with technological skills for solving societal problems.

\section{- An expert interviewed}

\footnotetext{
${ }^{14} \mathrm{~A}$ reviewer pointed out that many Muslim women are in favor of purdah because they believe it gives them privacy and security.
} 
particularly interesting to women because of their interests in the environment and their commitment to making a difference in their communities.

The experts say the fields of engineering of which women comprise half are biotechnology engineering, bioengineering, and environmental engineering. Therefore, the experts say, women can combine their desire to help society with technical skills for solving societal problems.

The experts point out that the environment is very important in many nations' agendas. In many parts of South America and India, the experts say, air pollution is already considered a problem. Other countries have defined food security and water pollution as high priority environmental problems. Sustainability (economic growth while preserving resources for the future) is considered an important global issue. Issues of cost and trade-offs are centrally important decisions that countries face.

Institutional Mechanisms. Mechanisms for the advancement of women are ineffective in most countries because of lacks of adequate resources and clear mandates, political leadership, and gender policy analyses.

Institutions that exist right now in most economies have grown out of the patriarchy.

The experts recommend that institutional mechanisms should be reexamined and redesigned to provide the outcomes women desire. Current institutional mechanisms result in outcomes that are the unintended consequences of historical factors. International Monetary Fund and World Bank policies are particularly noted.

The experts say that institutions currently constrain women from using their science and technology training because the women are not in positions of power - they tend not to direct scientific or funding institutions or to control budgets. Women are not in the majority that makes decisions. In developing countries, often there is no legislation to ensure equal access to jobs in science and technology nor is there equal pay for equal work.

The experts say that even when women are educated in science and technology, when the contributions that women bring to bear are not maximally supported and used in the systems in which they operate, their education comes to naught. Climates of receptivity to diversity that women bring to institutions are essential to sustaining women's contributions. Institutions need to provide for a critical mass of women so that - collectively and synergistically - women can make a greater impact than they can make alone. Institutional mechanisms needed include mentoring, hiring, and promotion policies to ensure that critical mass occurs and is maintained.

It would be helpful if both men and women were aware of situations, structures, and policies that create barriers for women, according to the experts. It would be helpful to document or monitor equity. The experts say that, at the international level, human, financial, and physical structures (such as laboratory equipment, office space, and computers) are needed. Gender-sensitive policies, such as family-friendly policies that often affect women the most, are needed. These include, for example, dual-hiring considerations, flexibility in work hours, child development and care facilities, eldercare facilities, opportunities for re-entry into science and technology fields after childbearing, management accountability for diversity, and equal pay for equal work. All these are needed to foster women's contributions. 
The experts consider modern mechanisms that protect intellectual property rights, such as copyright and trademarks, as particularly valuable. The experts recommend that these should be extended globally to include indigenous knowledge, so that women in the developing world can profit from their knowledge. ${ }^{15}$

Decision-making. Women remain underrepresented in decision-making positions in most spheres of economic, political, religious, athletic, arts, media, law, culture, and scientific activities.

The experts say that the only way women can be represented more is to be active in the 12 critical areas. A critical mass of women must be empowered and put in leadership positions to effect real change. If a woman is a token, she is isolated. There seem to be two ways of responding to this type of isolation: (1) women become passive or "mice," or (2) they stand up and make their points. Women who have entered the male domain are pioneers - they have gone where others fear to tread.

The experts say that women leaders are needed in business and industry; in academe; and in national, regional, state, and local governments. The experts stress the importance of women leaders bringing their perspectives to critically important issues and engaging their creativity in employing problem-solving approaches. The experts assert that societies must recognize they are not operating optimally until all their people are fully participating in power and decision-making positions.

An expert says the "knowledge era," in which economies are based more information than ever before, creates access to decision-making. Education and experience foster women's opportunities for an informed exercise of power and decision-making.

Poverty. Poverty disproportionately affects women and children; women have fewer economic opportunities than men; women lack autonomy; lack access to credit; lack control of land; laws and practices discriminate against women economically; social roles are rigid and inflexible; women are caught in subsistence level activities (gathering fuel, hauling water) with little or no time to develop economic activity.

Although the experts made few comments about poverty directly, they see poverty as linked with the economy. The experts say poor women have less access to educational opportunities than wealthy persons do and are more likely to have a child out of wedlock early in their lives. They say that poor women, rather than men, ordinarily take care of children born out of wedlock. Poor women are also less likely to be prepared for science and technology positions than poor men are. Women in poverty may lack access to

${ }^{15}$ A reviewer commented that the current system, heavily promoted by the United States in particular, requires private ownership of knowledge; the problem is that it cannot deal with community ownership, as is the case with traditional knowledge. Sui generis systems are being developed for living organisms. Another issue is that traditional knowledge can be protected from patenting if it is knowledge in the public domain, but many forms of traditional knowledge are sacred to just one part of the society or are secret. 
time-saving devices, and thus they have fewer discretionary hours for education. In the developing world, wages are insufficient to satisfy the needs of the family. Women are forced to work to bring in money.

One expert says that microcredit programs have been found to be effective in lifting families out of poverty in countries, like Bangladesh, where women are loan recipients. These women are serving markets internal to their region or country. The expert suggest that, for businesses that must export their products to the world market, women need access to loans that permit them to finance sound business plans. She said, "Women are good enough for big credit."

One expert expresses concern that international organizations emphasize "poverty alleviation" rather than "wealth creation." This difference in emphasis is critical, because programs with this emphasis tend to trap women in poverty and keep them marginalized. Women must have sufficient access to credit to establish businesses and enter the mainstream economy in their societies.

Human Rights. The international norms on human rights are not being implemented in many parts of the world, with discriminatory practices particularly affecting the human rights of girls and women.

One expert notes that Hillary Rodham Clinton said at Beijing, "Women's rights are human rights," demonstrating the importance of semantics and rhetoric used to describe women's rights. A major concern is human rights for women. Women are being used as political pawns in political problems all over the world. Rape is a major concern. As countries crumble, women's rights are not being championed.

The Girl Child. Girls are more vulnerable than boys to discriminatory practices, such as female genital mutilation, son preference, early marriage, lack of educational and training opportunities, kidnaping and sexual exploitation, practices related to health and food allocation, child labor exploitation, negative cultural attitudes and practices, and violence (both domestic and societal).

The experts believe that the problems of the girl child are significant. Yet, they also believe that, by addressing women's roles in science and technology through education and training, health, the economy, and communications, girl children will directly benefit.

Armed Conflict. Participation in armed conflict varies by gender; women suffer from rape, widowhood, and loss of children as a consequence of war; women lack power and authority in decisions leading to armed conflict.

The experts note that many conflicts are driven by economic disparity. If this problem can be dealt with, more people can be raised from poverty into the middle class. Then there will be less motivation to engage in conflict. And family values will be held higher in the culture (apart from domestic violence, which can still occur).

\section{Pathways to the Future}

The experts note that the developed and developing countries need to be parties on an equal footing when it comes to solving problems. Both need to respect the wisdom and rights of the others to achieve the perspectives that permit effective problem-solving. 
- One expert says philosophical statements are not enough; we need specific action steps. Governments should be held accountable for making action items occur, once they are funded. We need measurable, specific projects that promote girls' and women's access to education. Governments should create mechanisms that perform and trace progress and should hold certain officials accountable for the success of those mechanisms.
Dialogue is important. In our dialogue, we haven't found the voice for engaging one another constructively enough. We look at what is not working, and those responsible become defensive, and we are kept marginalized. We need to find the voice that allows me to say to you: "This is good; that is not working; let us fix it together."

- An expert interviewed

- Another expert recommends a two-pronged strategy: (1) help women's rights and activist organizations, development organizations, policy makers, and women in developing countries to realize and acknowledge the critical place of science and technology; (2) introduce a gender focus and women's issues into the worldwide science and technology agenda.

- An expert calls for recommendations for ways that women can gain access to positions that specifically influence the direction and application of science and technology.

- Governments should develop and implement science and technology strategies and programs that involve women.

- Those directing science and technology programs should be sensitive to their impact on society in general and on women in particular.

- Deal with the "digital divide" problem by expanding women's access to and use of the Internet globally.

\section{Ideas for Research}

- An expert notes that publicly available data on gender equity are needed. In Sweden, an office collects data, available to the public on women's participation in the work force. In the United States, the data are piecemeal — research projects are neither centrally located nor used to monitor the progress of women in science and technology.

- Another expert calls for greater involvement of social scientists in science and technology. Although hard science and technology have historically been the engines driving positive economic change in the United States, the negative impacts of hard science and technology could have been mitigated if social scientists had been engaged in the research and development. Today, social scientists are engaged in the human genome project and in climate change work. As we move along in the Information Age, the most valuable contributions will be those strongly influenced by social science, for example, the disciplines of cognitive psychology, decision-making, and operations research. New disciplines that are combinations of traditional ones, such as tools in decision theory and agent-based simulations, will form. People who can imagine the complex decision-making processes and the human dynamics involved in applications of technology have a different perspective and contribution from those of material scientists. Women could be involved in this, and it would be particularly helpful to the developing world. 


\section{Summary of the Experts' Views}

- The experts agree that science and technology are decisively important tools that can be used for the advancement of women in most or all of the 12 critical areas identified in the PFA.

- Although many people are skeptical about the prospects for benign applications of science and technology in their own cultures, the experts believe that women's involvement in the application of science and technology will lead to beneficial and productive uses.

- The experts believe that science and technology in the following four critical areas will affect all of the critical areas: education and training; economy (and economy linked with poverty); health; and communications/media. Experts were asked which of the 12 critical areas defined at Beijing would benefit most quickly from science and technology. The experts emphasize the four critical areas noted above and believe that science and technology in these areas will affect all the critical areas. For example, improved education and training in science and technology fields and applications will pave the way for women's involvement in leadership positions, which, in turn, would increase women's incomes and empower women in their communities. Access to improved communications would affect women's access to each other and promote their ability to organize politically.

- Although the 12 critical areas appear to be interrelated, the Western science community tends to look at the critical areas discretely when addressing applications to specific areas, or to view the critical areas as mainly political issues, not science and technology issues. The 12 critical areas are interrelated. The common theme appears to be the fundamental physical safety and well-being of women and children. The Western science community has not perceived its role in advancing women globally and has taken minimal action to address women's concerns in the developing world. At the same time, corporations have tended to view women as workers or markets to be exploited for profit. The Western science community tends to look at the 12 critical areas discretely when addressing applications to specific areas, rather than seeing the areas as synergistically interconnected. Also, the Western science community appears to see the 12 critical areas as falling more in the realm of politics than of science. Yet, synergism among the critical areas is a key finding, and it provides a way of approaching the involvement of science and technology in the advancement of women. There are, in fact, many entry points.

- The Internet is the one technology that most clearly appears to be embraced by both the developed and developing countries. The experts note potential negative impacts on women in most of the technology areas they discussed, especially on women in the developing world. For example, contraception is the most frequently cited example of health technology that helps women. Yet, women in certain developing countries have faced policies of forced sterilization that are based in health science. The one technology that appears to be embraced by both the developed and developing countries is the Internet. The major benefits of the Internet appear to be (1) the connectedness and community that develop through interpersonal communications; (2) access to both local and global markets that the Internet provides; (3) access to knowledge about local, national, and world trends and conditions - everything from education and training to weather reports to political, business, sports, health, and culture news; and (4) empowerment of women as active initiators, not just passive recipients, of information. 


\section{Analysis, Conclusions, and Recommendations}

\section{Analysis}

Perspectives on the role of science and technology differ greatly, depending in part on where one lives in the world and on one's organizational, network, and community affiliations. Generally, there appear to be three different perspectives on the role of science and technology in women's lives. Understanding these perspectives better may provide insights into promoting the use of science and technology in ways that women worldwide see as positive influences on their advancement. An analysis of the information provided by the experts suggests that three different perspectives regarding women, science, and technology exist.

- Pro-science perspective. One perspective supports Western science and technology as being pivotal to the advancement of women globally. From this viewpoint, educating women in Western science and technology will enable women everywhere to advance in scientific careers and become empowered to make decisions in scientific and technological fields. This view holds that the empowerment of women of science will result in significant advances in the 12 critical areas. From this standpoint, the presence of a critical mass of women in science and technology will lead to social conditions in which the physical safety and well-being of women and children will be improved.

- Relativist perspective. A second perspective supports Western science and technology, while acknowledging that science and technology can cause both positive and negative outcomes, as these are defined in different cultures. From this perspective, science and technology should be used to meet the needs of local cultures as the people define those needs - and, in particular, as women define those needs. Science and technology should blend with local knowledge for solving problems in ways that will benefit women. This perspective acknowledges the "truth" in different perspectives on science, technology, and women, and the belief that the impacts of science and technology should be assessed as part of technology applications.

- Skeptical perspective. A third perspective focuses on the use of science and technology for destructive or exploitative purposes, such as developing weapons of war or terminator technology. This perspective tends to see multinational corporations and scientists as conspiring to use the developing world's indigenous knowledge for profit, to see the developing world as a market for science- and technologybased goods (such as genetically engineered seeds) which may not be in the best interest of local communities, and to view science and technology as dominated by masculine concerns and indifferent to women's issues and voices. From this perspective, indigenous knowledge is locally preferable to Western-based science and technology, which is seen all too often as having been used to dominate and exploit developing countries.

\section{Conclusions}

Those with a pro-science perspective are inclined to view science as value-free and interchangeable among the world's cultures. Those with a relativist perspective take a step back from the two sides and acknowledge the truths in each perspective from the standpoint of its adherents. Those with a skeptical perspective emphasize negative aspects and tend to overlook positive outcomes of science and technology for women. 
The discovery of these divergent perspectives helps explain why citing examples of how science and technology have helped women will not change the behavior of those holding the various views. Most of the examples tend to support a pro-science perspective. Most of the negative examples reflect the skeptical perspective. Because people holding these perspectives have a vested interest in their organizations and networks, they are not easily swayed by examples emanating from the other side. These different viewpoints also appear to suggest a deep international power struggle for control over policy decisions and resources. Education alone, although always useful, will not resolve such a struggle.

A key impediment to progress appears to be the lack of accountability in science and technology programs to achieve specific, positive outcomes that advance women in the critical areas of concern. Analyses have been conducted, case study examples have been published, commissions and committees have been formed and have produced their reports. But progress in involving science and technology in women's critical areas still has been slow. A key impediment to progress appears to be the lack of accountability in science and technology programs with specific, achievable outcomes. Sufficient resources for visionary projects, coupled with firm accountability to an organization with authority, appear to be required for progress in applying science and technology to women's concerns.

To develop the kind of science literacy needed to make evident the connection between gender and science and technology, the history and philosophy of science must be taught along with the science. In the many discussions and studies leading up to and following the 1995 Beijing conference, and in the interviews with experts in the field, rich data and a strong rationale support the role of science and technology in the advancement of women in the critical areas of concern. Nevertheless, the inclusion of science and technology in the PFA remains a controversial topic. It seems apparent that something more is needed beyond information and examples. Could that "something more" be a different kind of education and training for science literacy, something beyond teaching "scientific facts" or science and technology content and skills?

A fully science-literate public would come to know that perceptions of science shift and change according to the "lens" worn by the perceivers. People in developing and developed countries alike would come to know that they, too, might be limited by the "lens" of cultural bias or historical precedent that they wear. Indifference to, or antagonism toward, science; techno-phobia; or even techno-worship may reflect that bias. Science and technology are, and have always been, value-laden. The questions asked by scientists - the purpose, design, and trade-offs of technologies - all are gender and cultural issues and always have been. Enlightened scientists, technologists, and policy leaders could come to know how to uncover values and biases in science and technology development that exclude all but their own culture and that often exclude women's perspectives and well-being completely.

The genie seems to be out of the bottle. One of the most difficult issues identified in this analysis is the tension between those taking a skeptical perspective toward science and technology (those seeing science and technology impacts on women as primarily negative) and the seemingly inexorable spread of Internet technology and the increasing globalization of trade. Nor can humanity "un-know" what it already knows. Even cultures in which the skeptical view is widespread will have difficulty insulating themselves from these powerful trends.

The question now appears to be, "How can women everywhere seek to master enough science, mathematics, and technology to decide on its applications and uses in relevant, beneficial ways?" Alternatives - which could include simply rejecting science, overthrowing the social order, or continuing the oppression of women - seem undesirable at best and have many negative consequences for women. 


\section{Recommendations}

First, we recommend that policy makers and educators encourage women-especially those with strong backgrounds in science, technology, and social science - to become experts in the ethics of science. Those with a strong interest in scientific ethics could do much to help define appropriate and beneficial uses of science and technology in their respective cultures. Because of women's interest and expertise in this area, it could become one of their greatest contributions.

We also recommend new studies be conducted on women's perceptions of the role that science and technology can play in advancing women in their areas of concern. Such research could help policy makers at national and international levels, as well as the Western scientific community itself, to better understand these issues. The result will be more informed decisions about how to incorporate women's concerns into scientific research programs and applications of science and technology.

Next, we recommend more in-depth analyses of institutional barriers to the advancement of women, science, and technology. One key barrier appears to be the emphasis on short-term rather than long-term benefits to developing nations. For example, Western and international organizations may be funding development projects that feature Western technology (and thereby new markets for Western technology), but they may not be funding projects that actually strengthen science and technology capacity development. International funding organizations may stress poverty alleviation, but they may not be investing in poorer nations' overall scientific and technological development in appropriate ways. A better understanding of institutional barriers can pave the way to institutional and policy changes that can make a difference for women everywhere.

We also recommend increased accountability in use of resources allocated for women's advancement. Indicators of success should be measured and those responsible for resources should be held accountable for achieving the intended outcomes. Funds made available to international and nongovernmental organizations for programs relevant to women's interests should be carefully monitored and results reported. A central repository of information and a data base should be established that contain this information, making comparative analyses possible.

We recommend that changes in education and training for women include more than ensuring that girls and women attend school, assured of unbiased curricula and skillful teachers. It is not enough to create nonsexist instructional materials and strategies; changes must occur more broadly and deeply in course content. To understand the actual and potential role of science and technology in the quality of the lives of women (and men), the philosophy and history of science and technology must be taught along with the science.

Finally, we recommend new mechanisms - such as convocations that meet frequently, new standing committees, and new participants - to foster dialogue among those with different perspectives - pro-science, relativist, and skeptical — on the role of science and technology in the advancement of women. Only through mutual respect and open communication can the world's women - and men - achieve a higher quality of life, in which the safety and well-being of all are ensured and the contributions of all are valued. 


\section{Bibliography}

Asia Pacific Economic Cooperation. May 2000. "Framework for the Integration of Women in APEC." http://www.apec.org.; site updated September 11, 2000.

Diaz-Sprague, R. 1999. "Women in Science in Latin America.” AWIS Magazine 11:2; pp. 33, 40.

Doyle, R. 2000. "Employment-Gender Disparity: Women and the Professions.” Scientific American (282:4); April, p. 30.

George, Y. S.; Gittler, A. U.; Bell, N. E. 1997. Global Linkages for Science Literacy Project: Reports from the Field on Promising Strategies for Educating Girls and Women in Science, Mathematics, and Technology. Washington, DC: American Association for the Advancement of Science.

George, Y. S.; Malcolm, S. M. 1999. "Excerpts Related to Women from the World Conference on Science." American Association for the Advancement of Science, September 3.

Homberger, D. 1997. "Eighth International Gender and Science and Technology Association Conference." AWIS Magazine 26:1; p.14.

Huyer, S. 1997. Supporting Women's Use of Information Technologies for Sustainable Development. Prepared for the Acacia Project, International Development Research Center, February 18.

International Institute for Sustainable Development (IISD). 1995. "A Final Report on the Fourth World Conference on Women." Earth Negotiations Bulletin 14:22; December.

International Institute for Sustainable Development (IISD). 2000. "Summary of the $44^{\text {th }}$ Session of the Commission on the Status of Women: 3-17 March 2000." Earth Negotiations Bulletin 14:34 (CSW-44, Summary).

Kegel-Flom, P. 1996. "Back from Beijing: A Call for Action.” AWIS Magazine 25:1, pp. 14-15.

Malcom, S.M. 1999. “Knowledge, Technology, and Development: A Gendered Perspective.” http://www. wigsat.org/malcom.html; site updated June 23, 1999.

Michels, K. 1996. “Gender, Science, and Technology: Platform for Action.” AWIS Magazine 25:1, p. 28.

Michels, K. 1996. "NGO Forum: Looking at the World (and Science) Through Women's Eyes." $A W I S$ Magazine 25:1; pp. 16-17.

Michels, K.; Schmoltner, A.; Samiei, H. 1996. "Women in Science Worldwide.” AWIS Magazine 25:1, pp.21-24.

National Science and Technology Council. 2000. Ensuring a Strong U.S. Scientific, Technical, and Engineering Workforce in the $21^{\text {st }}$ Century. Washington, DC: Executive Office of the President. 
NGO Communications Strategy Proposal. 1995. Beijing, China; http://www.igc.apc.org/beijing/fcom.html. Accessed April 13, 2000.

Oldham, G.; Achmad, S. 1999c."Gender Mainstreaming in Science and Technology-A Global Report." A Report on the Gender Mainstreaming in Science and Technology Thematic Meeting, World Conference on Science. Nature. Macmillian Publishers Ltd. 1999 Registered No. 785998 England.

Once and Future Action Network (OFAN). 1995. Science and Technology in the Beijing Declaration and Platform for Action. http://www.wigsat.org/ofan.

President's Interagency Council on Women. 1999. Federal Programs Benefiting Women and New Initiatives as Follow-Up to the UN Fourth World Conference on Women: 1999 Update-America's Commitment. Washington, DC: U.S. Department of State.

Schmoltner, A. 1997. "Beijing—One Year Later.” AWIS Magazine 26:1, pp.6-7.

Sulewski, H. 1996. "Mentoring Workshop at the NGO Forum.” AWIS Magazine 25:1, pp. 18-20.

UNESCO and ICSU. 1999. "Science Agenda-Framework for Action." World Conference on Science; July 1999, Budapest, Hungary. http://www.unesco.org/science/wcs.

UNIFEM. 1994. Special Issue on Women in Science and Technology. United Nations Development Fund for Women (UNIFEM) Newsletter.

UNIFEM. 1999. Women Making a Difference in Science and Technology: Case Studies. http://www.unifem.undp.org/wmdst/. Accessed May 7, 2000.

United Nations Advisory Committee on Science and Technology for Development. 1983. "Science, Technology, and Women: A World Perspective." Proceedings of the UN Ad Hoc Panel of Specialists; September 12-16, 1983, South Hadley, Massachusetts. Washington, DC: American Association for the Advancement of Science.

United Nations Commission on Science and Technology Development. 1995. Missing Links: Gender Equity in Science and Technology for Development. Gender Working Group, the International Development Research Centre in association with Intermediate Technology Publications.

United Nations Commission on the Status of Women. 1997. Followup to Beijing Implementation of the Strategic Objectives and Actions in the Critical Areas of Concern. http://www.un.org/ womenwatch/daw/csw.

United Nations. 1979. Convention on the Elimination of All Forms of Discrimination Against Women. http://www.un.org/womenwatch/daw/cedaw/index.html; site updated September 15, 2000.

United Nations. 1999a. "Declaration on Science and the Use of Scientific Knowledge." UN World Conference on Science. http://www.unesco.org/science/wcs. 
United Nations. 1995a. Report of the Fourth World Conference on Women, Beijing, China, 4-15 September 1995. (United Nations publication, Sales No. E.96.IV.13).

United Nations. 2000a. Emerging Issues Containing Additional Material for Further Actions and Initiatives for the Preparation of the Outlook Beyond the Year 2000. Report of the Secretary General, Third Session of the CSW 3-17 March 2000. (E/CN.6/2000/PC/1).

United Nations. 1995b. Excerpts from Agenda 21 Adopted by the United Nations Conference on Environment and Development (Earth Summit); June 3-14, 1992, Rio de Janeiro, Brazil. Commission on the Status of Women, 39 ${ }^{\text {th }}$ Session, 15 March - 4 April 1995.

United Nations. 1995c. Excerpts from the Vienna Declaration and Programme of Action, Adopted at the World Conference on Human Rights; 14-25 June, 1993, Vienna, Austria. Commission on the Status of Women, 39 ${ }^{\text {th }}$ Session, 15 March -4 April 1995.

United Nations. 1999b. Framework for Further Actions and Initiatives That Might be Considered During the Special Session of the General Assembly. Women 2000: Gender Equality, Development, and Peace for the $21^{\text {st }}$ Century. Report of the Secretary General, 15-19 March 1999. (United Nations publication E/CN.6/1999/PC/2).

United Nations Gender Working Group. 1996. Science and Technology for Sustainable Human Development: The Gender Dimension, Women in Global Science and Technology (WIGSAT) Network. http://gab.wigsat.org/unperfom.html.

United Nations. 2000b. Report of the Ad Hoc Committee of the Whole of the Twenty-third Special Session of the General Assembly; Beijing +5 Women 2000: Gender Equality, Development and Peace for the $21^{\text {st }}$ Century. 5-9 June 2000, New York. (United Nations publication, A/S23/10/Rev.1).

United Nations. 1996. Report of the UN Conference on Human Settlements (Habitat II). 3-14 June, 1996, Istanbul, Turkey. http://www.undp.org/un/habitat/agenda/ist-dec.html.

United Nations. 1994. Report of the International Conference on Population and Development, 5-13 September 1994, Cairo, Egypt. (United Nations publication, Sales No. E.95.XIII.18).

United Nations. 1995d. Report of the World Summit for Social Development. 6-12 March 1995, Copenhagen, Denmark. (United Nations publication).

United Nations. 1985. Report of the World Conference to Review and Appraise the Achievement of the United Nations Decade for Women: Equality, Development and Peace, Nairobi, 16-26 July 1985. (United Nations publication, Sales No. E.85.IV.10).

United Nations. 2000c. Science for the Twenty-First Century, A New Commitment. Report on the World Conference on Science. http://unesdoc.unesco.org

WomenWatch. 2000. "Summary of the WomenWatch Online Working Groups on the 12 Critical Areas of Concern of the Beijing Platform for Action." E/CN.6/2000/PC/CRP. 


\section{Appendix A. The 12 Critical Areas for the Advancement of Women Defined in 1995 by the U.N. Conference on Women in Beijing, China}

\begin{tabular}{|c|c|}
\hline Economy & $\begin{array}{l}\text { Discrimination by gender exists for women in hiring, remuneration, promotion, } \\
\text { working conditions, access to productive resources, and sharing of family } \\
\text { responsibilities. }\end{array}$ \\
\hline Education and training & $\begin{array}{l}\text { Discrimination by gender exists for women in education and training, especially } \\
\text { vocational training, training in science and technology, and continuing education; } \\
\text { women have a higher illiteracy rate than men. }\end{array}$ \\
\hline Environment & $\begin{array}{l}\text { The deterioration of the environment and depletion of natural resources negatively } \\
\text { affects the health and well-being of girls and women differently from boys and men. }\end{array}$ \\
\hline Health & $\begin{array}{l}\text { Discrimination by gender exists in access to quality health care and health information; } \\
\text { unequal relations exist in matters of sexual relations and reproduction. }\end{array}$ \\
\hline Media & $\begin{array}{l}\text { In most countries, the media project a negative and degrading image of women (i.e., } \\
\text { often violent and pornographic); women rarely reach media power positions. }\end{array}$ \\
\hline Poverty & $\begin{array}{l}\text { Poverty disproportionately affects women and children; women have fewer economic } \\
\text { opportunities than men; women lack autonomy; women lack access to credit; women } \\
\text { lack control of land; laws and practices discriminate against women economically; } \\
\text { social roles are rigid and inflexible; women are caught in subsistence level activities } \\
\text { (i.e., gathering fuel, hauling water) with little or no time to develop economic activity. }\end{array}$ \\
\hline Armed conflict & $\begin{array}{l}\text { Participation in armed conflict varies by gender; women suffer from rape, widowhood, } \\
\text { and loss of children as a consequence of war; women lack power and authority in } \\
\text { decisions leading to armed conflict. }\end{array}$ \\
\hline Decision-making & $\begin{array}{l}\text { Women remain underrepresented in decision-making positions in most spheres of } \\
\text { economic, political, religious, athletic, arts, media, law, culture, and scientific } \\
\text { activities. }\end{array}$ \\
\hline "The Girl Child" & $\begin{array}{l}\text { Girls are more vulnerable than boys to discriminatory practices, such as female genital } \\
\text { mutilation, son preference, early marriage, lack of educational and training } \\
\text { opportunities, kidnaping and sexual exploitation, practices related to health and food } \\
\text { allocation, child labor exploitation, negative cultural attitudes and practices, and } \\
\text { violence (both domestic and societal). }\end{array}$ \\
\hline Human rights & $\begin{array}{l}\text { The international norms on human rights are not being implemented in many parts of } \\
\text { the world, with discriminatory practices particularly affecting the human rights of girls } \\
\text { and women. }\end{array}$ \\
\hline $\begin{array}{l}\text { Institutional } \\
\text { mechanisms }\end{array}$ & $\begin{array}{l}\text { Mechanisms for the advancement of women are ineffective in most countries because } \\
\text { of lacks of adequate resources and clear mandates, political leadership, and gender } \\
\text { policy analyses. }\end{array}$ \\
\hline Violence & $\begin{array}{l}\text { Women are more subject than men to physical, sexual, and psychological abuse at } \\
\text { home, in communities, and in the workplace; they suffer from systematic violence } \\
\text { during war. }\end{array}$ \\
\hline
\end{tabular}




\section{Appendix B. List of the Experts Interviewed}

Suzanne Brainard, Ph.D., Director

Women in Science and Engineering

University of Washington

Immediate Past President

Women in Engineering Programs and Advocates

Network (WEPAN)

Seattle, WA

Patricia Campbell, Ph.D., President

Campbell-Kibler Associates

Groton, MA

Joy Clancy, Ph.D.

Senior Lecturer

Technology and Development Group

University of Twente

Enschede, The Netherlands

Founding Director, ENERGIA

Beatriz (Toni) Clewell, Ph.D., Director

Evaluation Studies

Gender Equity Research Program

The Urban Institute

Washington, DC

Catherine Jay Didion, Executive Director

Association for Women in Science

Washington, DC

Mildred S. Dresselhaus, Ph.D., Director

Office of Science

U.S. Department of Energy

Washington, DC

Institute Professor

Massachusetts Institute of Technology

Cambridge, MA

Yolanda S. George, Deputy Director

Directorate for Education and Human Resources

Programs

American Association for the Advancement of Science

Washington, DC

Sophia Huyer, Executive Director

Women in Global Science and Technology

Executive Director, Gender Advisory Board,

United Nations Commission on Science and

Technology for Development

New York, NY
Member, Once and Future Action Network (OFAN)

Grafton, Ontario, Canada

Susan Kemnitzer

Deputy Division Director (Education)

Engineering Education and Centers Division

National Science Foundation

Arlington, VA

Martha Krebs, Ph.D.

Former Director,

Office of Science

U.S. Department of Energy

Washington, DC

Member, Interagency Steering Committee

Commission on the Advancement of Women and

Minorities in Science, Engineering, and Technology

Development (CAWSET)

Susan Staffin Metz, Executive Director

Lore-El Center for Women in Engineering and Science

Stevens Institute of Technology

President,

Women in Engineering Programs and Advocates

Network (WEPAN)

Hoboken, NJ

Kathleen Michels, Ph.D., Program Officer

Fogarty International Center

Division of International Training and Research

National Institutes of Health

Bethesda, MD

Beverley J. Morgan, Managing Director

Blooming Things, Limited

Kingston, Jamaica

Wanda E. Ward, Ph.D., Deputy Assistant Director

Social, Behavioral, and Economic Science

National Science Foundation

Arlington, VA

Prof. Judi Wangalwa Wakhungu, Director

Women in Science and Engineering

College of Engineering

Pennsylvania State University

University Park, PA 


\section{Appendix C. Examples of Uses of Science and Technology for the Advancement of Women That the Experts Recommend Should be Further Investigated}

- Rita Colwell's research on the fever with microbes in Africa

- Barbara McClintock's work on biological organisms

- The role and impacts of electricity in displacing women's manual labor (e.g., washing machines) and in providing lighting, which affects women's education

- The way in which people in the developing countries miss opportunities to use helpful technologies because they do not have a "What will happen if I . . .?" mindset. For example, in Uganda, although it rains often enough, there is little drinkable water. Only the research centers have rain collectors; regular houses do not because most people do not see rain collectors as applying to them because of cultural norms.

- The career of Margaret Burbridge, a distinguished astronomer who won many prizes.

- The role of computers in providing equal work with equal pay for women.

- The role of science and technology in processing activities such as processing coconut oil.

- Women Inventors of the Philippines, a group that helps women produce food more efficiently and to market their products through street businesses

- A women at the University of Ghana trained in Ontario and now working on animal genetic resources.

- An African woman who redesigned and improved her own farming, leading to reduced soil erosion and more topsoil retainment.

- The Africa Digital Library, a Web site where people can download books to help in all areas

- Recapitulation of inventions by women, such as the Snuggly baby carrier, liquid paper, CFC recovery processes to recycle $\mathrm{CFCs}$, astrolabe for navigation, turtle power tiller-a small mechanical tiller of soil built for women, pushed by hand

- The role of science and technology in food production and cooking (women provide $90 \%$ of the food production for subsistence in Africa, but women do not produce the cash crops)

- The role of efficiency and solar cooking in reducing reliance on gathered wood for fuel

- The effectiveness of Mentornet, an industrial program which is developing mentor pairs in electronics

- The role of female scientists in Africa researching education, literacy, and health issues and changing communities through the application of their knowledge

- Ford's Windstar program, a mini-van developed largely by women engineers with women's preferences in mind

- The National Institutes of Health story in the United States, especially for its research on women's health issues such as breast cancer detection

- A case study of women in India, which has extreme diversity and a spectrum of well-educated and uneducated women living and working under a patriarchal system

- The unintended consequences of science and technology; for example, the green revolution, which provided incredible benefits but caused unintended negative consequences (e.g., the use of DDT as a pesticide and of herbicides leading to environmental damage and negative health impacts in the United States and the pollution of watersheds by fertilizer use).

- Development of a strain of rice with a high content of Vitamin A to support the immune system, sight, and ability to fight off basic diseases as well as AIDS; the International Rice Research Institute in Asia could have information on developments in this area

- In Africa, young women scientists want to include social science in their work to address the political social, and economic aspects of science 
- The International Development Research Center in Ottawa has an Acacia Project, which provides Internet connections to rural communities; for example, women making baskets for export can sell them in Nairobi and Kampala; the women arrange transport of their products with the buyer, thus doing away with middlemen and quadrupling their income (see Appendix E on the Acacia Project); solar-powered telecenters provide a venue for village people to receive e-mail, faxes, and phone calls

- A group of women in India were being raped and they organized and armed themselves; by getting weapons and training in their use, now the women are less victimized

- Ceramic stoves have been developed from a mixture of metal scrap and clay, which burn charcoal more efficiently, reduce particulates, and reduce the time and cost of charcoal burning in urban areas in Africa. 


\section{Appendix D. Additional Examples of the Role of Science and Technology in Advancing Women}

In interviews and in the literature, many examples emerged of the positive impact of science and technology on the advancement of women. The following are selected examples.

\section{Communications}

\section{The Acacia Project ${ }^{16}$}

The Acacia Initiative is an international action research project led by the International Development Research Centre (IDRC) to empower sub-Saharan African communities to use information and communications technologies (ICTs) for their own social and economic development. Initially the project, which began in 1997, is focusing on Mozambique, Senegal, South Africa, and Uganda. Acacia works primarily with rural and disadvantaged communities, particularly with women and youth groups who have been isolated from ICT networks, to discover and demonstrate how they can use ICTs to solve local development problems. Goals are improved "connectivity" within communities and human and organizational capacities to understand and use ICT tools, information, and the knowledge connectivity brings.

A community telecentre is planned within each of the participating countries as the mechanism to provide voice, fax, email and Internet access with, for example, telemedicine, distance education, municipal governance services, news distribution, training, and information on markets, crops, and weather conditions.

Among research issues being pursued are exploration of gender differences in the ways in which men and women access, use, and derive benefits from ICTs. The research will address such questions as the extent to which women propagate ICTs in Africa; their roles as users, providers, and technicians; their social status; the role for less advantaged women; the obstacles to using ICTs that women face; the potential for using ICTs to promote women's interests, including equity; and the ways in which women's groups might organize to exploit ICTs.

Acacia integrates research, demonstration, and action to address an overarching hypothesis: "that connectivity and access to ICT-based tools, information, and knowledge can enable communities to solve their development problems and reverse the trend toward marginalisation." Acacia seeks to integrate the contributions of various partners such as researchers and policymakers. Acacia also plans an evaluation of program efforts to determine whether individual projects are appropriate, efficient, effective, sustainable, and capable of duplication.

Acacia is also exploring the presentation of Internet information in audio format to make it available to illiterate people. The main question is whether the use of audio can extend the availability of Internet-based information and whether illiterate and non-English speakers can gain access to the wealth of information available to those in the literate First World. A chief question is whether the substantially strange new world opened up to the illiterate will be perceived as relevant and have beneficial applications. Acacia's premise is that the consequences of inaccessibility in the undeveloped world to the rapidly accelerating changes in the developing world are widening gaps that spell disaster for all involved.

\footnotetext{
${ }^{16}$ www.idrc.ca/acacia, accessed in May 2000.
} 


\section{Energy}

While the search for energy is a major daily drive for the rural poor, it is especially burdensome for women. In most developing countries, women spend far more time than men engaged in energy-related survival activities such as firewood collection, food processing, and water hauling, leaving little time for other activities. Almost one billion adults are illiterate. Two-thirds are women, and of the estimated 125 million young children not attending primary school in developing countries, two-thirds are girls. More than one billion people are affected by waterborne diseases: cholera, typhoid, dysentery, schistosomiases, and other diseases are cause $\mathrm{d}$ by polluted water and lack of sanitation. Children are especially susceptible. Diarrheal diseases, often transmitted in polluted drinking water, are responsible for the deaths of 2-4 million children annually, almost one-quarter of all child deaths.

Energy plays a central role in finding solutions to these staggering problems that disproportionately impact rural women and children in developing countries. Without energy there can be little economic development, clean water, refrigerated foods and medicines, no telephones, radios, televisions, computers, and the Internet.

\section{Village Power Initiative}

The Village Power Initiative, through the U.S. Department of Energy's National Renewable Energy Laboratory (NREL), is working to bring clean and affordable renewable energy to hundreds of millions of rural people throughout the world who have no access to electric power. Countries that have received assistance include Mexico, the Dominican Republic, Brazil, Argentina, Chile, South Africa, Ghana, Indonesia, The Philippines, China, and Russia. Projects have ranged from rural electrification for village residents, schools and community centers to water pumping, desalination and disinfection of water, and development of cleaner cooking and transport fuels for populations suffering from extreme pollution and air-quality problems.

Among the projects are the following:

- In Ghana, 12 unelectrified communities will receive renewable energy electricity services to benefit health clinics, schools, potable water supplies, public lighting, and telecommunications.

- Eight villages in the Ganges River delta have received financing to purchase affordable solar home systems to improve the quality of life and economic productivity. A village health clinic will receive a vaccine refrigerator. A local NGO will train young people to maintain and operate the equipment.

- In the Philippines, an island solar battery charging station eliminated the necessity of having to go by boat to recharge batteries. The project has provided work for local women who record and collect fees for the battery charging.

- Plans exist to expand the provision of solar home systems to 10,000 households in six northwestern provinces of China and to install 4,000 photovoltaic and wind systems for households and villages in Inner Mongolia. 


\section{Vietnam Women's Union Project}

The Vietnam Women's Union project involved the Solar Electric Light Fund, the Rockefeller Fund, and the U.S. Department of Energy's Sandia National Laboratory. The project trained local technicians who assembled solar electric home systems using photovoltaic panels for homes and community centers.

The 11 million strong women's Union was the project's driving force. Women are the recognized decision makers on domestic issues that affect energy consumption. Through a revolving loan fund, they make credit available for PV system purchase. The cost of the solar home systems was $\$ 300$. Ninety-five percent of the loan payments were made on time, and there were no defaults. Effects of the project included income generation, extended business hours, increased safety for women, and increased time spent in education and entertainment.

\section{Gender and Energy Implications for Health in Tibet}

Boulder, Colorado, and Lhasa, Tibet, have had a Sister City relationship since 1986. Dr. Bill Warnock, an international development consultant with degrees in electrical engineering and astronomy, has been president of the Boulder-Lhasa Sister City Project (BLSCP) in Boulder for 11 years. He has made nine trips to Tibet, and is planning a tenth. Between 1991 and 1993, he recruited 12 American doctors and led them to Tibet to conduct skill exchanges with doctors at the Lhasa City Hospital. Five specialties were represented: OB-GYN, ophthalmology, internal medicine, emergency medicine, and dentistry. During 1992, the American team performed the first artificial-lens implant surgery for cataract ever done in Tibet.

As a consultant for NREL, Dr. Warnock has led the BLSCP Solar Electricity Program for Tibetan nomads and farmers in the Lhasa Prefecture. With funding and participation by the U.S. Department of Energy (DOE) and NREL, 20-watt photovoltaic systems have been provided for 200 rural homes during 2000. Through the leadership of Andre van Rest, DOE Program Manager, and Dr. David Renne, NREL Project Manager, subcontractors have installed the solar home systems and have produced business development strategies. The major system components will be American equipment and the systems have been installed by businesses based in Nepal.

Tibetan nomads and farmers suffer from a deadly parasite. Two species of the Echinococcus tapeworm parasite, causes of the cystic (CE) and alveolar (AE) forms of echinococcosis, are known to afflict animals on the Tibetan Plateau. These infections can be transmitted to humans when they accidentally ingest the egg-stage of the tapeworm passed in the feces of infected dogs or foxes. Between June 1997 and June 1998, Dr. Peter Schantz, Centers for Disease Control and Prevention in Atlanta, Georgia, conducted a systematic survey of echinococcosis in the human and animal populations in five counties on the Tibetan Plateau. Cases in humans were diagnosed by abdominal ultrasound, chest x-ray, and blood tests. Of a total of 7702 who underwent the examinations, 435 persons (5.6\%) were diagnosed as positive. Female participants had consistently higher rates $(6.8 \%)$ than male participants $(4.6 \%)$.

Dr. Warnock has hypothesized that gender role differences for the rural Tibetan lifestyle could be a contributing factor to echinococcosis infections. The Tibetan herds are composed of yak, sheep, and goats. The diet consists mostly of roasted barley, yak-butter tea, meat, cheese, and yogurt. Women take care of the household, milk the animals, and cook the meals. Men set up and take down the yak-hair tents, herd the animals, and perform the butchering. Cyst-laden viscera of slaughtered yak and sheep are fed to the local dogs. Yak dung is the cooking fuel the women use. Most of the nomads and farmers appear not to 
understand the source of the parasitic disease and the important role that sanitation can play in its prevention. Further analysis of the data is under way, and one or more publications on the situation are planned.

Although the causes are complex, differences in gender roles and in women's use of energy play a role in the etiology of this fatal parasitic disease. Science and technology are helping with the research on the prevalence of this illness, analysis of the causes of its spread, and potential prevention of transmission and infection.

\section{Water}

\section{Nigeria}

Nigeria, with a newly elected civilian government, reached out to the United States for assistance in a number of areas, including energy. Secretary Richardson visited Nigeria to discuss cooperation between Nigeria and the United States in the energy sector. In 1999, the two governments signed a Memorandum of Cooperation on Energy.

The Nigerian government was interested in implementing a project involving a solar-powered ultraviolet water purification system, developed by one of the Department of Energy's national laboratories. The Department's scientists visited the village of Kuje, Nigeria, and tested the water wells to identify potential water quality problems. It was determined that the village would benefit from a water purification system.

The village women are responsible for the village's water supply. The women were consulted about the project, and they said that, in addition to a holding tank for purified water for consumption, they would like to have a second holding tank for nonpurified water that they could use for purposes other than human consumption.

The ultraviolet water purification system, which is powered by solar cells, or PV, was designed to meet the needs and wishes of the village women by providing two holding tanks, one orange in color for purified water, and the other yellow for nonpurified water.

Energy Secretary Richardson attended the dedication of the system, which was also attended by the Nigerian Minister of Power and Steel, other Nigerian officials, and the U.S. Agency for International Development (USAID). USAID plans to replicate the solar water purification system in 150 other villages in Nigeria. 


\section{Appendix E. Prince Charles Attacks the Scientific Community ${ }^{17}$}

Ray Moseley of the Chicago Tribune reported on May 25, 2000, that Great Britain's Prince Charles has "turned his fire on the scientific community." Charles has been speaking out against genetically modified foods and scientific engineering of the environment. Charles was quoted as saying, "Nature has come to be regarded as a system that can be engineered for our own convenience . . . and in which anything that happens can be fixed by technology and human ingenuity." Charles reportedly said that science lacks a spiritual dimension and should be used not to change, but to understand, nature. He called for a new balance between "the heartfelt reason of instinctive wisdom and the rational insights of scientific analysis" and warned against treating the Earth as a "great laboratory of life, with potentially disastrous long-term consequences." Moseley reported that Charles has no scientific training but has been influenced by environmentalists and agriculturists.

Scientists have responded vigorously to Charles' attacks. Richard Dawkins, a renowned Oxford university biologist, was quoted as saying, "I forget who it was who remarked: 'Of course we must be open-minded, but not so open-minded that our brains drop out." Dawkins said that agriculture has always been "unnatural." "A wheat grain is a genetically modified grass seed, just as a Pekinese is a genetically modified wolf. Playing God? We've been playing God for centuries."

Moseley quoted Dawkins as saying, "If we want to sustain the planet into the future, the first thing we must do is stop taking advice from nature, quoting Charles Darwin's remark about 'the clumsy, wasteful, blundering, low and horribly cruel works of nature."

Hugh Pennington of the University of Aberdeen, a leading expert on food safety, was quoted as saying, "If we went down the scientific route Prince Charles is proposing, the health of the nation would suffer and life expectancy might decrease." Improvements in health and environment are based on tampering with nature, he said. His belief is there is no natural balance in nature. "The ultimate fate of every species is to be made extinct and to fight that threat. If science had not affected that balance, we would all be living at least 30 years less."

Derek Burke, former chairman of the British government's Advisory Committee on Novel Foods and Processes, was quoted as saying, "It is a sense of wonder that drives many scientists to marvel at God's creation, from Newton to the present day."

But Charles was supported in his view by environmentalists such as Lord Melchett, head of Greenpeace UK, and Tony Juniper, policy director of Friends of the Earth. Charles is seen as representing a wide body of opinion in Europe that is hostile to genetically modified foods. Supermarkets in Britain and elsewhere in Europe routinely assure their customers that they have no genetically modified food products on their shelves.

\footnotetext{
${ }^{17}$ Boulder Daily Camera, Thursday, May 25, 2000, p. 19A.
} 


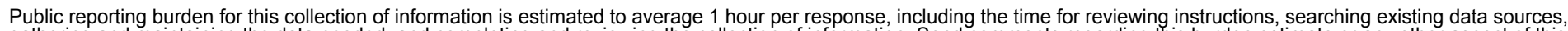

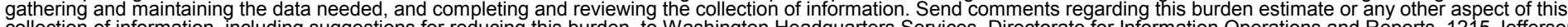
Davis Highway, Suite 1204, Arlington, VA 22202-4302, and to the Office of Management and Budget, Paperwork Reduction Project (0704-0188), Washington, DC 20503.
1. AGENCY USE ONLY (Leave blank)

$$
\text { 2. REPORT DATE }
$$
3. REPORT TYPE AND DATES COVERED
September 2000
Technical report

4. TITLE AND SUBTITLE

The Role of Science and Technology in the Advancement of Women Worldwide

6. AUTHOR(S)

Irene Hays, Barbara Farhar

7. PERFORMING ORGANIZATION NAME(S) AND ADDRESS(ES) REPORT NUMBER

5. FUNDING NUMBERS

T: EROM.1000

9. SPONSORING/MONITORING AGENCY NAME(S) AND ADDRESS(ES)
National Renewable Energy Laboratory
1617 Cole Blvd.
Golden, CO $80401-3393$

11. SUPPLEMENTARY NOTES

NREL Technical Monitor:

12a. DISTRIBUTION/AVAILABILITY STATEMENT

National Technical Information Service

U.S. Department of Commerce

5285 Port Royal Road

Springfield, VA 22161

13. ABSTRACT (Maximum 200 words)

Participants at the 1995 Fourth World Conference on Women, held in Beijing, China, created a Platform for Action focusing on 12 critical areas of concern (poverty, education and training, health, violence, armed conflict, economy, decision-making, institutional mechanisms, human rights, the media, environment, and the girl child) and the serious barriers to women's health and well-being in each area. Subsequently, the Department of Energy funded a study, described here, that shows, in a literature review and in interviews with 15 women experts, how science and technology can be integral to women's advancement in each of the 12 critical areas. Among the study's conclusions are that differing perspectives exist (proscience, relativist, and skeptical) on the role of science and technology in women's lives and that these differing perspectives may explain why communication is difficult among policy makers and with scientists about the role science and technology may play in the advancement of women worldwide. Recommendations call for women's involvement in the ethics of science; removal of institutional barriers to advancing women; greater accountability in use of resources; changes in science education; and increased dialogue among those with differing perspectives on the role of science and technology in the advancement of women.

14. SUBJECT TERMS FWCW; UN; Beijing; international; developing countries; women; poverty; education; health; violence; armed conflict; economy; decision-making; human rights; science; technology; barriers

15. NUMBER OF PAGES

16. PRICE CODE

17. SECURITY CLASSIFICATION OF REPORT Unclassified
18. SECURITY CLASSIFICATION OF THIS PAGE Unclassified
19. SECURITY CLASSIFICATION OF ABSTRACT Unclassified
20. LIMITATION OF ABSTRACT

UL 